\title{
Cellular Control of Renin Secretion
}

ARMIN KURTZ

\section{Contents}

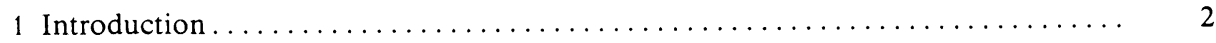

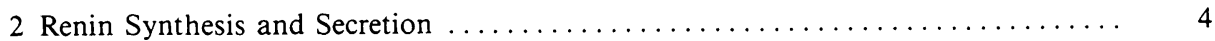

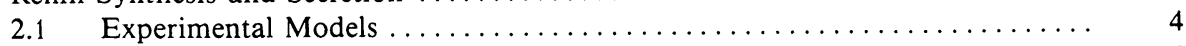

2.2 Processing of Renin in Juxtaglomerular Cells . . . . . . . . . . . . . . . 6

2.3 Mechanisms of Renin Secretion .......................... 8

3 Intracellular Signals for the Control of Renin Secretion ................. 10

3.1 General Remarks.................................... 10

3.2 Regulation of Calcium in Renal Juxtaglomerular Cells ............... 11

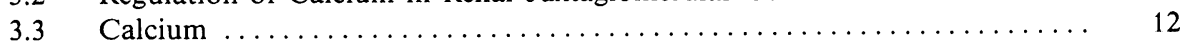

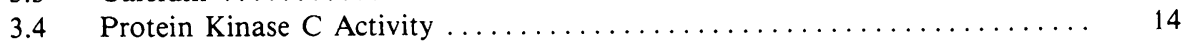

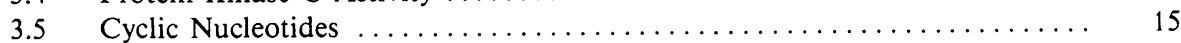

3.5.1 General Remarks......................................... 15

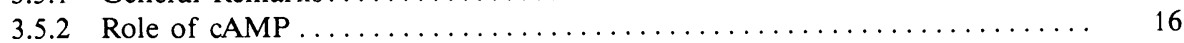

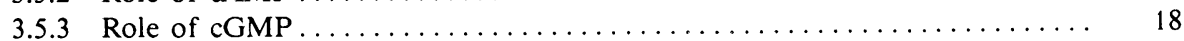

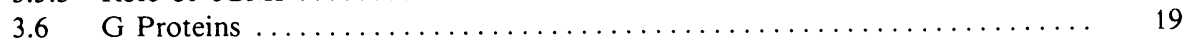

$3.7 \quad$ Membrane Potential . . . . . . . . . . . . . . . . . . . . . . . . . . . 21

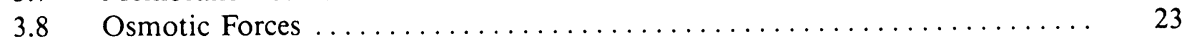

4 Possible Explanations for the "Calcium Paradox" .................. 23

5 Physiological Environment of Juxtaglomerular Cells ................... 25

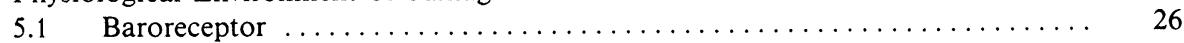

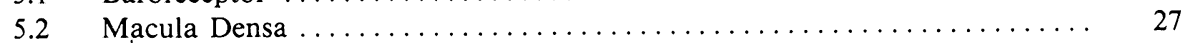

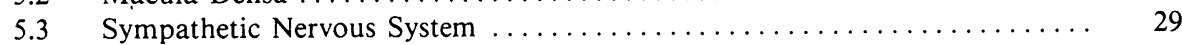

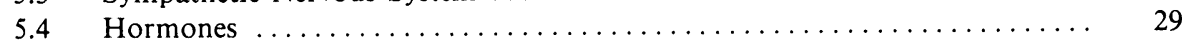

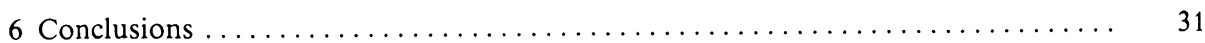

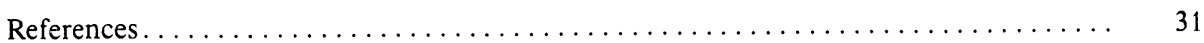

Physiologisches Institut der Universität Zürich, Winterthurerstrasse 190, CH-8057 Zürich, Switzerland 


\section{Introduction}

The renin angiotensin aldosterone system (RAAS) is one of the basic regulatory mechanisms for controlling extracellular volume and blood pressure. The activity of the RAAS is mainly controlled by the rate of renin release into the circulation. The presence of renin has been demonstrated in a variety of tissues, including kidney, salivary glands, placenta, blood vessels, and various endocrine glands (Campbell 1987). Although renin obtained from these tissues, in particular from the submaxillary gland, has been important for the elucitation of the structure and intracellular processing of renin (Panthier et al. 1982; Cantazaro et al. 1983), so far only renal renin has proved important in the regulation of the RAAS. Therefore, unless otherwise indicated, only renal renin is considered in this review.

Within the kidney, renin is produced and stored, and then released from the so-called granular juxtaglomerular cells (Barajas 1979; Taugner et al. 1984). These cells are modified smooth muscle cells and are located in the tunica media of the afferent arteriole, adjacent to the glomerulus (Fig. 1). Morphologically they resemble vascular smooth muscle cells, but have with some typical

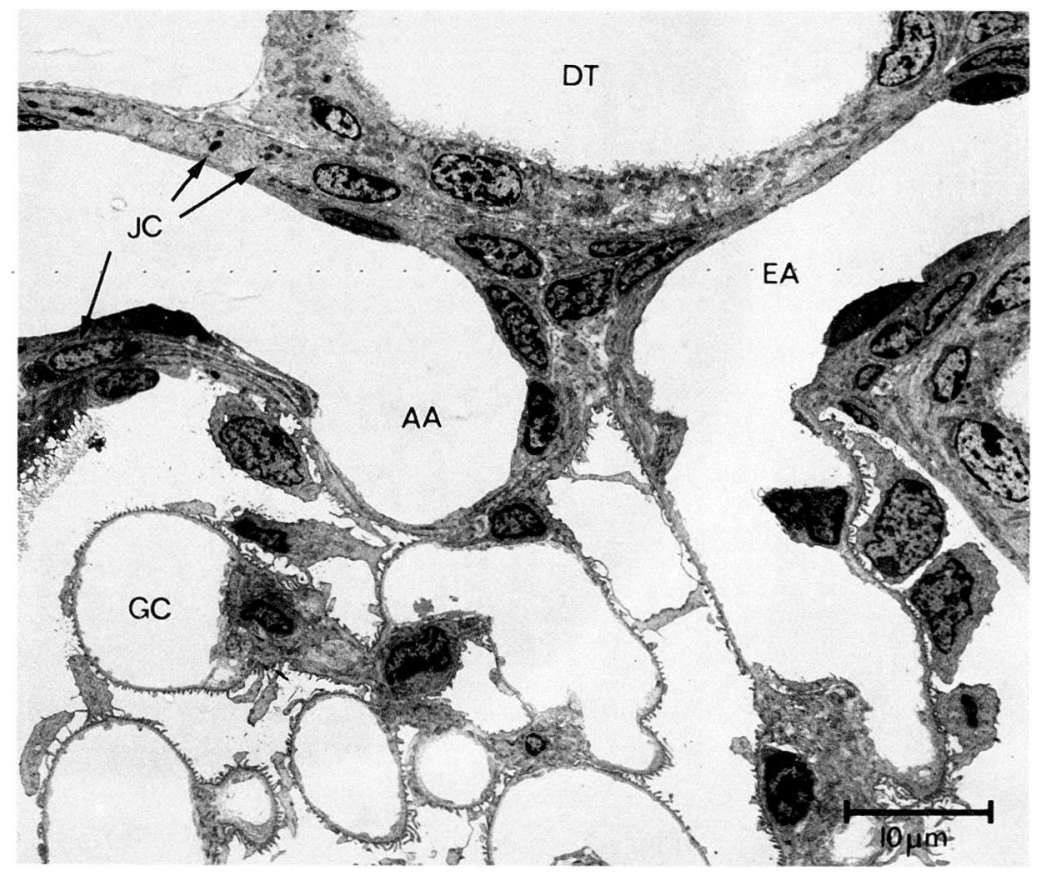

Fig. 1. Electron micrograph of a iuxtaglomerular apparatus in mouse kidney. $J C$, juxtaglomerular cell; $D T$, distal tubule; $A A$, afferent arteriole; $E A$, efferent arteriole; $G C$, glomerular capillary. Courtesy of Maria Harlacher, Heidelberg 
characteristics of secretory cells, namely a well-developed endoplasmatic reticulum, a prominent Golgi apparatus and membrane-bound granules containing renin (Barajas 1979; Taugner et al. 1984).

Since the rate of renin release from juxtaglomerular cells has a direct effect on blood pressure, and because an enhanced rate of renin release is known to be a major cause of hypertension, the mechanisms controlling renal renin release have attracted interest among physiologists, pharmacologists, and clinicians.

So far, four basic mechanisms for controlling renin release from the juxtaglomerular cells have been identified (Davis and Freeman 1976; Keeton and Campbell 1981). These are:

1. Intrarenal blood pressure

2. Influence exerted by the macula densa segment of the distal tubule

3. The sympathetic nervous system

4. Humoral factors

Despite a large body of findings on the modulation and alteration of renal renin release, the intracellular mechanisms by which renin release is controlled within juxtaglomerular cells are not clearly understood.

During the last decade the physiological and pharmacological mechanisms which alter renin release have been sufficiently reviewed (Davis and Freeman 1976; Keeton and Campbell 1981; Fray et al. 1983 a, b; Hackenthal et al. 1983; P.C. Churchill 1985; Vallotton 1987). This review therefore focuses on the intracellular processes that govern renin release from juxtaglomerular cells. The available information is discussed in relation to present knowledge of general mechanisms of secretion. It has been shown for a variety of secretory cells, including those of the adrenal and pituitary glands, exocrine and endocrine cells of the pancreas, neutrophils and platelets, that the secretory process is triggered by guanosine triphosphate - (GTP-)binding (G)-proteins (Burgoyne 1987), phosphoinositide turnover (Berridge 1987), intracellular levels of calcium (Penner and Neher 1988), and cyclic nucleotides (Rasmussen and Barrett 1984).

Evidence exists which indicates that the cytoskeleton (Hall 1982) and cellular electrical properties (Petersen and Maruyama 1984) have roles in the regulation of secretory processes. Therefore, special consideration is given in this review to the role of cytoskeleton, calcium, cyclic nucleotides, phosphoinositide turnover, $G$ proteins, and the electrical properties of juxtaglomerular cells in the control of renin release. In this context, our own results, obtained from studies on isolated rat juxtaglomerular cells, are presented.

The effects of the four basic mechanisms which control renal renin release and how, these can be explained by present knowledge of the intracellular control of renin release, are also discussed in this review. 


\section{Renin Synthesis and Secretion}

\subsection{Experimental Models}

As with many other basic physiological investigations, the study of the intracellular control of renin cannot be primarily performed in humans. Therefore, the results described in the following paragraphs have been obtained predominantly with rats, mice, and dogs. No essential differences in the control of renin release between rats, mice, dogs, and humans have been discovered so far. Therefore, it is assumed that the findings obtained with preparations from laboratory animals are also representative for humans.

The main reason for the absence of detailed knowledge about the cellular control of renin release is the lack of suitable experimental models. Obtaining insight into intracellular mechanisms within juxtaglomerular cells from studies using whole kidney preparations is difficult. The effect of a substance found to alter renin release in these preparations may result from a variety of causes, i.e., a direct action on juxtaglomerular cells, an influence on either the baroreceptor or macula densa receptor, an alteration in the activity of the intrarenal sympathetic nervous system, or altered sensitivity of the juxtaglomerular cells to certain hormones. To circumvent these problems experimental models have been devised which allow more direct access to juxtaglomerular cells. The hydronephrotic kidney model (Bührle et al. 1986a) is considered to be free from tubular influence, and experiments studying renin release from renal cortical slices are performed assuming that the baroreceptor and the macula densa are inactive in these preparations (Keeton and Campbell 1.981). Other approaches to obtaining a more direct insight into processes within juxtaglomerular cells are the use of microdissected afferent arterioles (Itoh et al. 1985 a, b), isolated glomeruli containing fractions of the afferent arteriole (Blendstrup et al. 1975), and the use of suspensions of isolated renal cortical cells (Lyons and Churchill 1975; Khayat et al. 1981). The disadvantage of all these preparations, however, is that the percentage of juxtaglomerular cells is low.

It is clear that hydronephrotic kidneys, renal cortical slices, isolated glomeruli, and renal cortical cell suspensions are not optimal for metabolic studies on juxtaglomerular cells, since the tissues used are obviously not fully representative. This disadvantage led to increased efforts to develop experimental models containing a higher percentage of juxtaglomerular cells. In 1982 Rightsel et al. succeeded in cloning juxtaglomerular cells from rat kidneys, but unfortunately, these cells had only a very low renin content. Moreover, the cloned juxtaglomerular cells did not develop the renin-containing secretory granules which are typical of juxtagiomerular cells in situ. Galen et al. (1984) suggested that cultured human tumoral juxtaglomerular cells could be a use- 


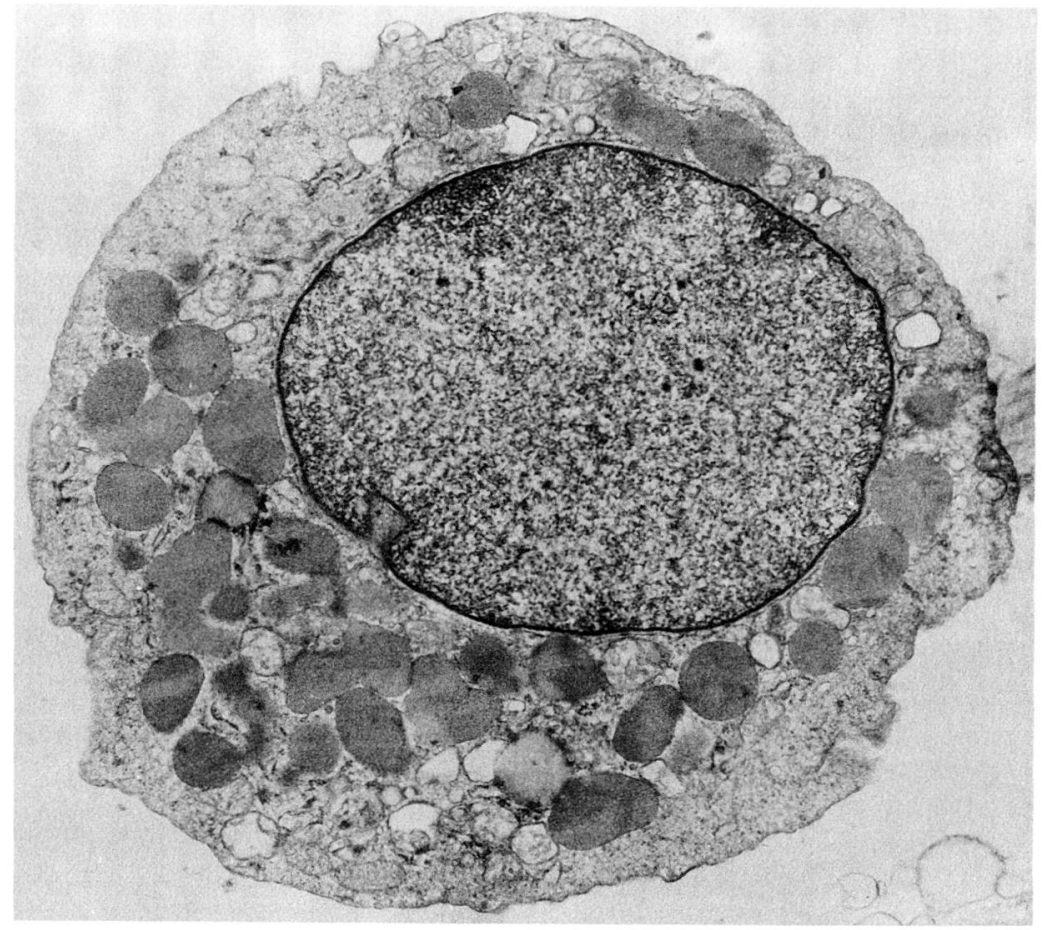

Fig. 2. Isolated juxtaglomerular cell from rat kidney. Note the numerous secretory granules. Isolation was done according to Kurtz et al. (1986b). $\times 16000$

ful tool for studies concerning the mechanism of renin release, but these are not generally available. It was later discovered that these cultured tumoral cells do not contain typical secretory granules and that they release renin mainly in an inactive form. Recently, the same group succeeded in transforming cultured tumoral juxtaglomerular cells by the use of SV 40 virus infection (Pinet et al. 1985). Although these cultures are not optimal for the study of exocytosis of renin they could be very valuable for the investigation of the control of renin and prorenin synthesis (Pinet et al. 1987).

Our own efforts concentrated on the development of a method that allows reproducible production of a cell preparation containing a high proportion of juxtaglomerular cells. Using rats we were able to produce cell preparations containing around $80 \%$ juxtaglomerular cells (Kurtz et al. 1986a,b). These cells display prominent renin granules (Fig. 2) and they spontaneously release renin, predominantly in the active form (Kurtz et al. 1986a). Moreover, the renin release can be modulated by a variety of agents that typically regulate renin release in the kidney (Kurtz et al. 1984, 1986a). Utilizing a similar technique, Johns et al. (1987) recently established cell preparations with high 
renin content, and it was confirmed that the preparations are also suitable for the study of renin secretion a cellular level.

\subsection{Processing of Renin in Juxtaglomerular Cells}

Present knowledge of the intracellular synthesis of renin is summarized in Fig. 3. The molecular biology has recently been reviewed in detail (Dzau et al. 1988), and the structure of the human renin gene has already been eluci-

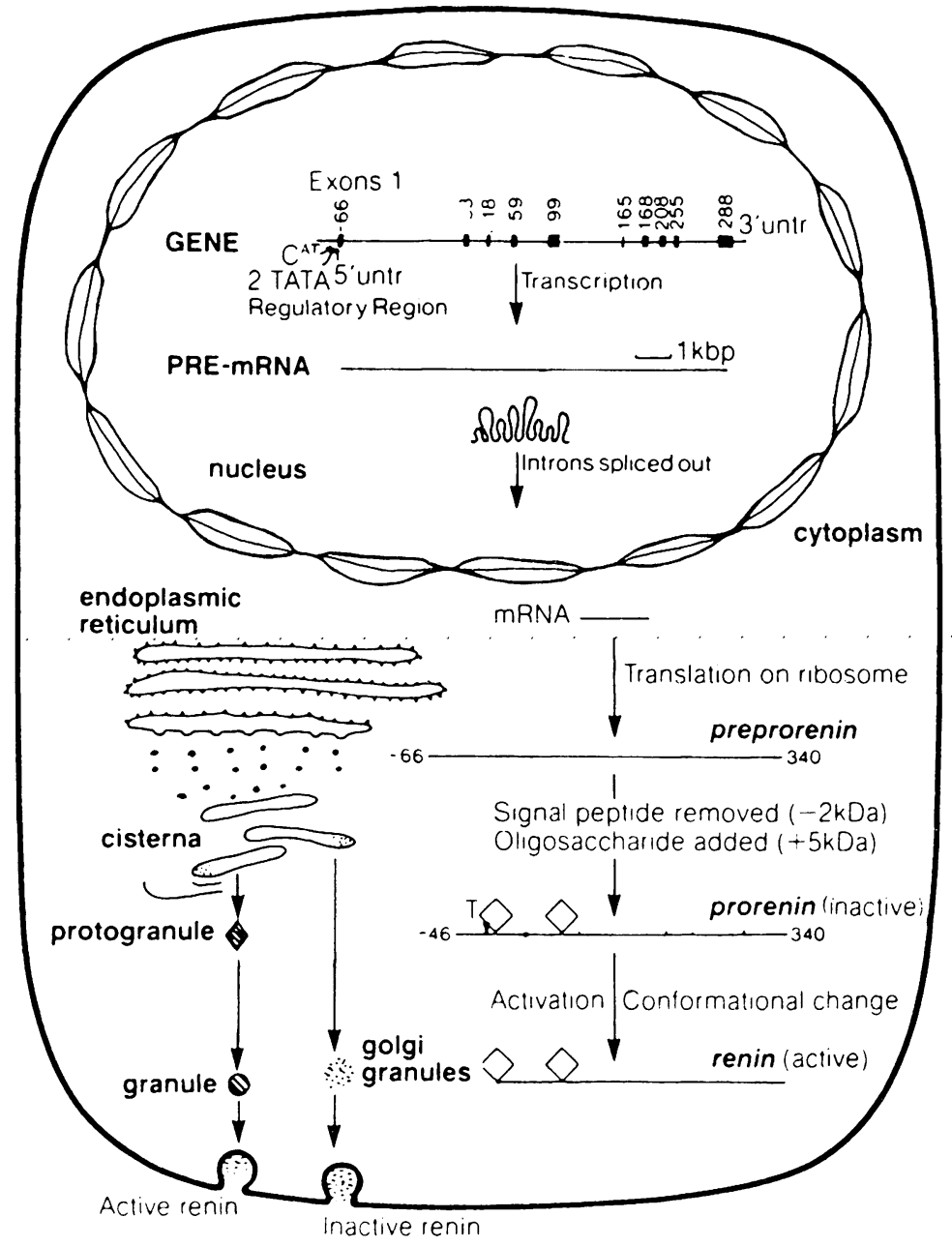

Fig. 3. Biosynthetic pathway of active renin in a juxtaglomerular cell from its gene to its release into the blood stream. (From Vallotton 1987) 
dated (Hardman et al. 1984; Horbart et al. 1984). Human renal renin is encoded by a single gene which consists of ten exons and nine introns. The messenger (m) RNA of the renin gene is translated into a protein preprorenin consisting of 401 amino acid residues (Imai et al. 1983; Pratt et al. 1983). In the endoplasmic reticulum a 20 -amino-acid signal peptide is cleaved from preprorenin, leaving prorenin a glycosylated protein of 381 amino acids (Panthier et al. 1982; Cantanzaro et al. 1983; Galen et al. 1984). Prorenin, which is enzymatically inactive, is packed into secretory granules at the Golgi apparatus; where it is further processed into active renin by the cleavage of a 46-amino-acid peptide from the $\mathrm{N}$-terminus of the molecule. Mature renin is a monomeric glycosylated carboxypeptidase, with a molecular weight of around 44000 daltons. In addition, the structure of the renal renin gene in rats has been clarified (Burnham et al. 1987; Fukamizu et al. 1988).

Two greatly different morphological forms of granules with renin immunoreactivity can be distinguished within juxtaglomerular cells (Barajas 1966; Taugner et al. 1984). It is thought that only mature granules contain active renin. The subcellular classification of renin-containing granules is still a matter of debate. Two main types of cellular granules originate from the Golgi apparatus: the first is the typical secretory granules, which contain material to be released from the cell by an exocytotic process, and the second is lysosomes. These granules contain proteolytic and other hydrolytic enzymes. The content of lysosomes is usually bound to remain within cells and to catalyze autolytic processes. The mechanism that causes secretory granules to fuse with the cell membrane but allows lysosomes to remain within the cytoplasm is not clearly understood. Morphological differences between secretory granules and lysosomes exist. In contrast to secretory granules, lysosomes have autophagic capabilities (De Duve 1983). In addition, the lipid content of lysosomal membranes can be enhanced by so-called lysosomotropic substances such as chlorphentermine and chloroquine whilst that of typical secretory granules cannot (Houban et al. 1972; Hillmann-Rauch 1975).

Renin has been found to originate from the Golgi apparatus, like typical secretory products (Pratt et al. 1983). Since renin is a proteolytic enzyme, and such enzymes are normally stored within lysosomes, the possibility that renincontaining granules might be related to lysosomes has been considered for some time (Fisher 1966). This speculation has furthermore been confirmed by the discovery that typical lysosomal enzymes such as acid phosphatase (Fisher 1966; Ruyter 1964) and $\beta$-glucuronidase (Gomba and Soltesz 1969) coexist with renin in the granules. More recently, renin granules have been shown to display autophagic capabilities, and they also gradually accumulate polar lipids after administration of lysosomotropic substances (Taugner et al. 1985 a). Overall, present knowledge of the nature of renin-containing granules within juxtaglomerular cells supports the idea that the renin granule is not a typical secretory granule, but rather resembles a modified lysosome. 
Information on the intracellular control of active renin production is rather scarce. At least three regulatory steps in the production of mature renin can be identified, namely, the transcription rate of the gene, the translation rate of mRNA, and the rate of conversion of prorenin into renin. The proteolytic mechanism by which prorenin is processed into renin is not clearly understood. In view of the findings that cathepsins are capable of converting prorenin to renin in vitro (Takahashi et al. 1982), and that cathepsins B and D coexist with renin in secretory granules (Taugner et al. 1985 b, 1986), it might be speculated that these cathepsins have an important function in the intracellular activation of renin. For completness, it should also be mentioned that kallikrein has been considered as a possible activator of prorenin (Yokosawa et al. 1979).

At present it is not known whether the intragranular cleavage of prorenin is subject to physiological regulation. There are, however, findings indicating that both the transcription rate of the renin gene and the translation rate of the renin mRNA are subject to physiological regulation. It is well established that states of low sodium intake into the organism are accompanied by high levels of plasma renin (Keeton and Campbell 1981). Using rats, Nakamura et al. (1985) have shown that sodium depletion and converting enzyme inhibition led to a 46 -fold increase in plasma renin activity a 1.5 -fold increase in renal renin activity, and a 2.8 -fold increase in renal renin mRNA content compared with normal animals. The latter finding indicates that the gene transcription rate is subject to control, and assuming that the biological half-life of plasma renin is not altered in states of low sodium intake, it follows from the results of these experiments that the translation rate of a single renin mRNA molecule is also enhanced in this situation. This conclusion is in agreement with the results obtained by Morimoto et al. (1979); who found that low sodium intake in rats caused a 12 -fold increase in plasma renin activity and a 3-fold increase in granular renin activity. Further confirmation of transcription and translation regulation was recently obtained by Moffet et al. (1986), who found that aorta coarctation led to a 50-fold increase in renin mRNA and renin enzyme activity in the ischemic kidney. However, identification of the cellular factors that control transcription and translation of the renin gene remains a task for future research.

\subsection{Mechanisms of Renin Secretion}

Components of the cytoskeleton, e.g., microtubules and microfilaments, are necessary for cell motility and intracellular translocation processes (Trifaro et al. 1985). Since a typical secretory process requires the movement of secretory granules from within the cell to the cellular plasma membrane, there is speculation that the cytosolic part of the cytoskeleton is involved in this process 
(Lacy et al. 1968; Sherline et al. 1977; Hoffstein and Weissmann 1978). The subplasmalemmal part of the cytoskeleton, however, is considered to have an inhibitory role in secretion (Burgoyne et al. 1987, 1988). Significant alterations in the arrangement of microfilaments in the space between the secretory granule and the cellular membrane have been observed upon secretion (Hall 1982; Boyd 1982). Moreover, it has been found that the typical secretory process in a variety of secretory cells can be altered by substances which interfere with the normal assembly of microtubules and microfilaments (Hall 1982; Boyd 1982; Perrin et al. 1987). In view of these findings the question arises of the role of the cytoskeleton in the secretion of renin granules from juxtaglomerular cells.

Juxtaglomerular cells have been found to be rather poor in their content of microfilaments and microtubules (Taugner et al. 1984). No significant alteration in the arrangement of microfilaments upon secretion of renin has been observed in juxtaglomerular cells (Taugner et al. 1984). Furthermore, it has been demonstrated in whole kidneys and in kidney slices that colchicine, which interferes with the normal assembly of microtubules, has no inhibitory effect on the secretion of renin from juxtaglomerular cells (Hackenthal et al. 1978). In our own studies using isolated juxtaglomerular cells and colchicine we did not observe alterations in spontaneous renin release (Kurtz et al. unpublished).

Since there is no positive evidence that the microfilament system plays an active role in the extrusion of renin, it is uncertain whether renin release requires translocation of secretory granules at all. In fact, it has been suggested that renin could be released from storage granules into the cytoplasm of juxtaglomerular cells, and then may pass through the plasma membrane. This idea was first discussed by Rouiller and Orci (1971), and then later revived by Fray et al. (1983 a,b) and Barajas and Powers (1984). Experimental evidence, however, is rather limited, and is based on the finding that isolated renin granules release more renin in the presence of a low calcium concentration (Sagnella and Peart 1979). Since a fall in the cytosolic calcium concentration is believed to be a stimulatory signal for renin release (see Sect. 3.3), it has been hypothesized that a fall in cytoplasmic calcium sets in motion the release of renin from the granules into the cytoplasm and finally across the plasma membrane. Recently, Zavagli et al. (1983) reported morphological evidence of cytoplasmic solubilization of renin granules. Support for this mechanism of renin release was also provided by Fray and Lush (1984), who found that upon stimulation of renin release the renin activity increased in the cytosolic phase of a kidney extract, whilst that of the granular fraction remained unchanged. It should be mentioned, however, that the experimental protocol used in this study did not allow cytoplasmic renin and extracellular renin which might have been released by exocytosis to be clearly distinguished.

In contrast, there is strong morphological evidence that renin release from juxtaglomerular cells occurs as an exocytotic process involving fusion be- 
tween the membranes of the secretory granule and the plasma membrane (Taugner et al. 1984). But how is the contact between these two membranes brought about in juxtaglomerular cells? Peter (1976) obtained morphological evidence of deep, channel-like invaginations of the plasma membrane in rat juxtaglomerular granulated cells. He inferred that renin secretion represents an unusual type of exocytosis in which the plasma membrane invaginates towards the granules, thus providing sites for extrusion, instead of the granules moving towards the cell surface prior to release. This idea was supported by the findings of Ryan et al. (1982), which showed that the incidence of these deep invaginations increases during stimulus induced degranulation and decreases during regranulation of juxtaglomerular cells. Recent electron-microscopical studies performed by Taugner et al. (1984), however, show that granules lying next to the juxtaglomerular cell membrane change their shape upon stimulation of secretion by protruding towards the cell membrane, but the reason for this is not clear. Morphological evidence indicates that structural alterations within the renin granule accompany this protrusion process (Taugner et al. 1984). The authors speculated that these intragranular alterations are due to changes in osmolarity of the granules; however, the mechanism for these changes of intragranular osmolarity upon stimulation of secretion in juxtaglomerular cells is not known.

Taugner et al. (1987) obtained morphological evidence showing that not only mature granules but also juvenile granules, which contain mostly prorenin fuse with the juxtaglomerular cell membrane. This observation could explain the origin of prorenin in the plasma. In humans, for instance, prorenin can account for up to $90 \%$ of the total amount of renin present in the plasma (Sealy et al. 1986). Further evidence that renin is released by an exocytotic process was provided by Skott.(1986). Using isolated afferent arterioles, he observed a quantum-like release of renin from these arterioles. This mode of renin release could be explained by the exocytosis of single secretory granules containing renin.

In summary, it appears likely that renin is released from renal juxtaglomerular cells by an exocytotic process which involves fusion of the granule's membrane and the cellular plasma membrane. However, the mechanism, by which the contact between the two membranes is brought about is not yet clear.

\section{Intracellular Signals for the Control of Renin Secretion}

\subsection{General Remarks}

In recent years it has become evident that the phosphatidylinositol cycle (PI cycle) plays a major role in the stimulus-secretion coupling of secretory cells 
(Berridge 1984). Stimulators of secretion usually activate a specific plasma membrane-bound phosphodiesterase, phospholipase C (PLC) which splits phosphatidylinositol-4,5-bisphosphate into diacylglycerol (DAG) and inositol triphosphate $\left(\mathrm{IP}_{3}\right) . \mathrm{IP}_{3}$ releases calcium from intracellular stores in the endoplasmic reticulum, and consequently leads to a rise in the intracellular concentration of calcium (Streb et al. 1983), while DAG stimulates a phospholipid-dependent protein kinase C (Nishizuka 1984). There is good experimental evidence to indicate that exocytosis in a typical secretory cell is initiated or facilitated by the rise in calcium induced by $\mathrm{IP}_{3}$ (Penner and Neher 1988). The secretory response is then maintained, or even enhanced, both by the activation of the $C$ kinase by DAG and by an increased transmembrane calcium influx caused by the opening of calcium channels in the plasma membrane (Rasmussen 1986; Alkon and Rasmussen 1988). Activation of voltage-gated calcium channels is an additional process by which secretion from excitable cells is triggered.

In view of the importance of calcium and $C$ kinase activity it is obvious to consider the role of these in the control of renin release from juxtaglomerular cells.

\subsection{Regulation of Calcium in Renal Juxtaglomerular Cells}

Only limited information exists on the regulation of calcium within juxtoglomerular cells, mainly due to the paucity and difficult accessibility of these cells. Recently a combination of patch clamp and calcium microfluorimetry was utilized to gain insight into the regulation of calcium within single juxtaglomerular cells (Kurtz and Penner 1989). The results obtained indicate that juxtaglomerular cells contain intracellular stores of calcium which can be mobilized by receptor-operated and G-protein-mediated stimulation of PLC activity.

It is interesting that activation of PLC sets in motion oscillations of intracellular calcium (Fig. 4). The frequency of these oscillations is positively correlated to the extracellular concentration of calcium. Moreover, calcium release in juxtaglomerular cells is dependent on the membrane potential; membrane hyperpolarization facilitates calcium release and membrane depolarization blocks calcium release. Clear evidence for hormone-induced transmembrane calcium influx has been found (Kurtz and Penner 1989; Kurtz et al. 1986a). In this study no positive evidence for the existence of voltage-operated calcium channels (VOCC) was obtained. The presence of VOCC in juxtaglomerular cells, however, cannot be definitively ruled out as a result of this study, because it is known that VOCC can display very fast run-down kinetics in vitro (Tanita 1988). 


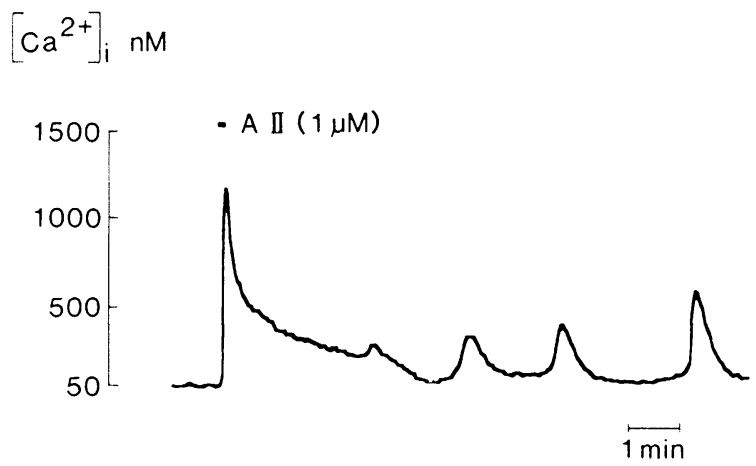

Fig. 4. Oscillations of intracellular calcium in renal juxtaglomerular cells induced by angiotensin II $(1 \mu M)$. (Adapted from Kurtz and Penner 1989)

\subsection{Calcium}

Although there are some individual findings suggesting a positive role for calcium in renin release (Morimoto et al. 1970; Iwao et al. 1974; Lester and Rubin 1977; Ginesi et al. 1981), much evidence argues in favor of an inhibitory role. Results obtained from experiments with whole kidneys, renal cortical slices, renal glomeruli, and isolated juxtaglomerular cells indicate that the rate of renin release is inversely related to the extracellular concentration of calcium (Kisch et al. 1976; Watkins et al. 1976; Fray 1977; Kotchen et al. 1977; Harada and Rubin 1978; Fray and Park 1979). Since the intracellular and extracellular calcium concentrations are positively correlated (Kurtz and Penner 1989) the rate of renin release is expected to be inversely related to the intracellular concentration of calcium as well.

Additional information on the role of calcium in the intracellular regulation of renin release was gained from experiments in which the calcium extrusion from juxtaglomerular cells was blocked. Calcium extrusion from a cell is generally brought about by two processes: (1) a sodium-calcium exchange mechanism (Baker 1976), and (2) energy-dependent calcium adenosine triphosphatase (ATPase) (Baker 1976; Rasmussen and Barret 1984). The sodium-calcium exchange is driven by the sodium gradient between the extracellular and intracellular spaces (Blaustein 1974). Since this gradient is maintained by the activity of sodium-potassium ATPase, the function of the sodium-calcium exchange is linked to the activity of the sodium-potassium ATPase. Consequently inhibition of sodium-potassium ATPase by ouabain blocks the sodium-calcium exchange. Therefore, ouabain leads to an accumulation of calcium within the cell and consequently to a rise in the intracellular calcium concentration. Ouabain has been found to inhibit renin release (Lyons and Churchill 1974; Park and Malvin 1978; P. C. Churchill 1979; Part et al. 1981; P.C. Churchill and M.C. Churchill 1982a), and this inhibition has been shown to be a calcium-dependent process (Park and Malvin 1978; P. C. Churchill 1979; Cruz-Soto et al. 1984). Inhibition of calcium ATPase by vanadate 
partly inhibits the extrusion of calcium, and therefore leads to a rise in the intracellular calcium concentration (O'Neal et al. 1979). Vanadate has also been found to inhibit renin release (P. C. Churchill and M. C. Churchill 1980; Lopez-Novoa et al. 1982). These findings suggest that a rise in the intracellular calcium concentration inhibits the secretory process in the juxtaglomerular cells.

It has been observed that spontaneous renin release from whole kidneys, kidney slices, glomeruli, and isolated juxtaglomerular cells is inhibited by facilitation of calcium entry (Flynn et al. 1977; P.C. Churchill and M. C. Churchill 1982a,b, 1987; M.C. Churchill et al. 1983; Matsumara et al. 1984; Raguki et al. 1988), and is enhanced by calcium entry blockers (P. C. Churchill et al. 1981; Abe et al. 1983; Kurtz et al. 1984; Antonipillai and Horton 1985). Inhibition of calcium release from intracellular stores has also been reported to enhance renin release (Fray and Lush 1984). In addition, calcium mobilizing hormones such as angiotensin II, vasopressin, norepinephrine, and platelet activating factor have been found to inhibit renin release by a calcium-dependent process (Vandongen and Peart 1974; Vandongen 1975; P. C. Churchill 1981; Kurtz et al. 1984; Pfeilschifter et al. 1985). Using isolated juxtaglomerular cells, it was shown that these hormones also enhanced transmembrane calcium influx into the cells (Pfeilschifter et al. 1985; Kurtz et al. 1986a), and that renin release from juxtaglomerular cells is inversely correlated to the transmembrane calcium influx. We and others have shown that the inhibitory effect of these calcium mobilizing agents can be attenuated, or even abolished, by calcium channel blockers such as verapamil (P.C. Churchill 1980; Part et al. 1981; Kurtz et al. 1986a).

In summary, all the findings mentioned above support the idea that the rate of renin release from juxtaglomerular cells is inversely related to the calcium concentration in these cells. Thus renin secretion behaves strikingly differently from the typical secretory mechanism in which the secretion rate is positively correlated to the intracellular calcium concentration (Rasmussen 1986). The mechanism by which intracellular calcium inhibits the secretory process in juxtaglomerular cells is still unknown.

Calcium-dependent reactions are usually triggered by calcium in two ways, either by the action of ionized calcium, or by calcium-binding proteins. Calmodulin is one of the most important calcium-binding proteins in smooth muscle cells with respect to its quantity and function. The question as to whether the inhibitory effect of calcium on renin release could be mediated by calmodulin has been addressed by investigating the effect of calmodulin antagonists on renin release. Indeed, calcium calmodulin antagonists stimulate renin release from rat glomeruli (Kawamura and Inagami 1983), rat renal cortical slices (P.C. Churchill and M. C. Churchill 1983; Matsumara et al. 1984; Antonipillai and Horton 1985; Part et al. 1986), isolated perfused rat kidneys (Fray et al. 1983 b; Schwertschlag and Hackenthal 1983), and isolated 
juxtaglomerular cells (Kurtz et al 1984). However, there is some concern that these findings may not really prove an essential role for calmodulin in the inhibition of renin secretion by calcium. For instance, we found in our studies that trifluoperazine, which is the most commonly used calmodulin antagonist in the study of renin secretion, also inhibits the transmembrane calcium influx into the juxtaglomerular cells (Kurtz et al. 1984), a fact that is also known from studies on other tissues (Seeman 1972). It is, therefore, difficult to decide from these experiments whether the stimulation of renin secretion is due to calmodulin inhibition, or to inhibition of calcium influx. The calmodulin antagonist W7, which apparently does not affect the calcium conductance of the cell membrane, was also reported to stimulate renin release (Matsumara et al. 1984); however, inhibition of cyclic adenosine monophosphate (cAMP) phosphodiesterase cannot be excluded. Since cAMP is considered to be a stimulatory signal for renin release (see Sect. 3.5) it is not definitely clear from this study whether or not inhibition of calmodulin is the reason for the stimulation of renin release by W7.

In summary then, although there is much evidence that calmodulin antagonists stimulate renin release, clear proof that calmodulin mediates the inhibitory effect of calcium on renin secretion is still lacking.

\subsection{Protein Kinase C Activity}

As mentioned previously, the exocytotic process in a number of secretory cells is initiated by a rise in the intracellular calcium concentration and is sustained of facilitated by the activity of protein kinase $C$. These intracellular events are normally caused by the activation of plasma membrane-bound phospholipase C (PLC), which splits polyphosphoinositides into inositol phosphates and diacylglycerol (DAG) (Berridge 1984). DAG is considered to be the physiological intracellular activator of protein kinase C (Nishizuka 1984).

It has been shown that hormones which cause breakdown of phosphatidylinositol bisphosphate in isolated juxtaglomerular cells such as angiotensin II, arginine-vasopressin, norepinephrine, and platelet activating factor increase the content of DAG within the cells, suggesting stimulation of protein kinase $\mathrm{C}$ by these hormones (Pfeilschifter et al. 1985; Kurtz et al. 1986a). These hormones also inhibit renin release from the cells. Since activation of PLC causes both calcium mobilization and activation of protein kinase $\mathrm{C}$, and since calcium mobilization is considered to be an inhibitory signal for renin release, it is difficult to evaluate the role of protein kinase $C$ in these experiments. Direct stimulation of protein kinase $\mathrm{C}$ activity can be achieved by tumor-promoting phorbol esters such as 12-O-tetradecanoylphorbol-13-acetate (TPA) (Castagna et al. 1982). TPA, when added either to isolated juxtaglomerular cells (Kurtz et al. 1986a, b,c) or to renal cortical slices (Churchill and Churchill 
1984), leads to a dose-dependent inhibition of renin release; a significant effect, however, was only observed with rather high concentrations of TPA. At high concentrations TPA is also suspected of acting as a calcium ionophore, independently of its activating effect on C-kinase (Castagna et al. 1982). Since an enhanced calcium influx brought about by a calcium ionophore would be expected to inhibit renin release, a direct inhibitory effect by TPA on renin release cannot be excluded. Churchill and Churchill (1984), however, provided indirect evidence that the inhibitory effect of TPA on renin release from kidney slices was not due to an ionophore effect. In our own studies we have found that TPA enhances transmembrane calcium influx into isolated juxtaglomerular cells (Kurtz et al. 1986a). It is, therefore, not yet clear whether TPA inhibits renin release by the phosphorylation of as yet unknown proteins via $\mathrm{C}$ kinase activation or by enhancing calcium influx independently of $\mathrm{C}$ kinase activation.

Despite the uncertainty about the way phorbol esters affect renin release, it can at least be said that activation of $C$ kinase does not stimulate the secretory process in juxtaglomerular cells. In this respect, the secretory mechanism in juxtaglomerular cells seems to differ significantly from that of other endocrine and exocrine cells.

\subsection{Cyclic Nucleotides}

\subsubsection{General Remarks}

Cyclic nucleotides, in particular cyclic adenosine monophosphate (cAMP) and cyclic guanosine monophosphate (cGMP), are capable of modulating the secretory response initiated and maintained by calcium and protein kinase $\mathrm{C}$ activity.

Activation of adenylate cyclase is known to be an important signal for the regulation of secretion in different types of secretory cells. In contrast to the effect of calcium, the effect of cAMP on the secretion process is not uniform (Rasmussen and Barrett 1984); cAMP can either enhance the secretory response, e.g., in pancreatic cells), or even decrease the secretory response, e.g., in platelets or mast cells (Penner and Neher 1988). The mechanism by which cAMP affects secretion in these cells has not been elucidated in detail, but it seems likely that cAMP exerts its effect by the activation of a cAMP-dependent protein kinase. Moreover, there is growing evidence that cAMP affects the secretion process by interfering with calcium and $C$ kinase activity.

Recent findings indicate that cGMP is capable of inhibiting the secretory response in some cell types. Matsuoka et al. (1985) have shown the inhibition of aldosterone secretion from adrenal glomerulosa by atrial natriuretic peptide is associated with an increase in cGMP production. In addition, it was 
demonstrated that cGMP attenuates exocrine pancreatic secretion stimulated by cholecystokinin (Otsuki et al. 1986) or protein kinase C (Rogers et al. 1988).

In view of the effects of cyclic nucleotides on the secretory response in typical secretory cells, possible effects on the control of renin release should be considered.

\subsubsection{Role of cAMP}

There is broad evidence that substances which activate adenylate cyclase such as $\beta$-catecholamines (Davis and Freeman 1976; Keeton and Campbell 1981), prostaglandins (Gerber et al. 1978; Hackenthal et al. 1980; Weber et al. 1976; Wernig et al. 1971), glucagon (Udea et al. 1978; Vandongen et al. 1973), and parathyroid hormone (Powell et al. 1978; Smith et al. 1979) stimulate renin release. Application of membrane-permeable cAMP analogs also enhances renin secretion (Peart et al. 1975; Viskoper et al. 1977). Furthermore, inhibition of cAMP phosphodiesterase leads to stimulation of renin release (Peart et al. 1975; Viskoper et al. 1977). These findings were obtained using isolated perfused kidneys, kidney slices, isolated renal glomeruli, and isolated juxtaglomerular cells. Using isolated juxtaglomerular cells, we showed that activators of adenylate cyclase such as isoproterenol, prostacyclin, and forskolin increase the cellular content of cAMP (Fig. 5) (Kurtz et al. 1984).

The question arises by which mechanism cAMP stimulates renin release. In particular, it must be considered whether cAMP influences renin release directly or indirectly by decreasing the intracellular calcium concentration. Using isolated juxtaglomerular cells, we obtained evidence that the rate of renin release is correlated to the intracellular level of cAMP in the presence of activators of adenylate cycles. However, an increase in the level of cAMP was found not to be a prerequisite for the stimulation of renin release. In the presence of the calcium channel blocker verapamil and the calmodulin antagonist trifluoperazine we observed a two- to threefold increase in the rate of renin release a figure that is comparable with the effects of isoproterenol and prostacyclin on renin secretion. Verapamil and trifluoperazine, however, had no effect on the cellular cAMP level. Agents known to inhibit renin release such as angiotensin II did not influence the cAMP level (Kurtz et al. 1984). These findings suggest that CAMP is at least not the dominant regulator of renin release from juxtaglomerular cells.

Four lines of experimental evidence suggest that cAMP may stimulate renin release by interference with the intracellular concentration of calcium in juxtaglomerular cells:

1. It has been shown that cAMP inhibits calcium mobilization from intracellular stores in single juxtaglomerular cells (Kurtz and Penner 1989). 
Fig. 5. cAMP levels in isolated rat renal juxtaglomerular cells (upper panel) and renin activity measured by angiotensin I $(A I)$ production (lower panel) after addition of prostacyclin and isoproterenol
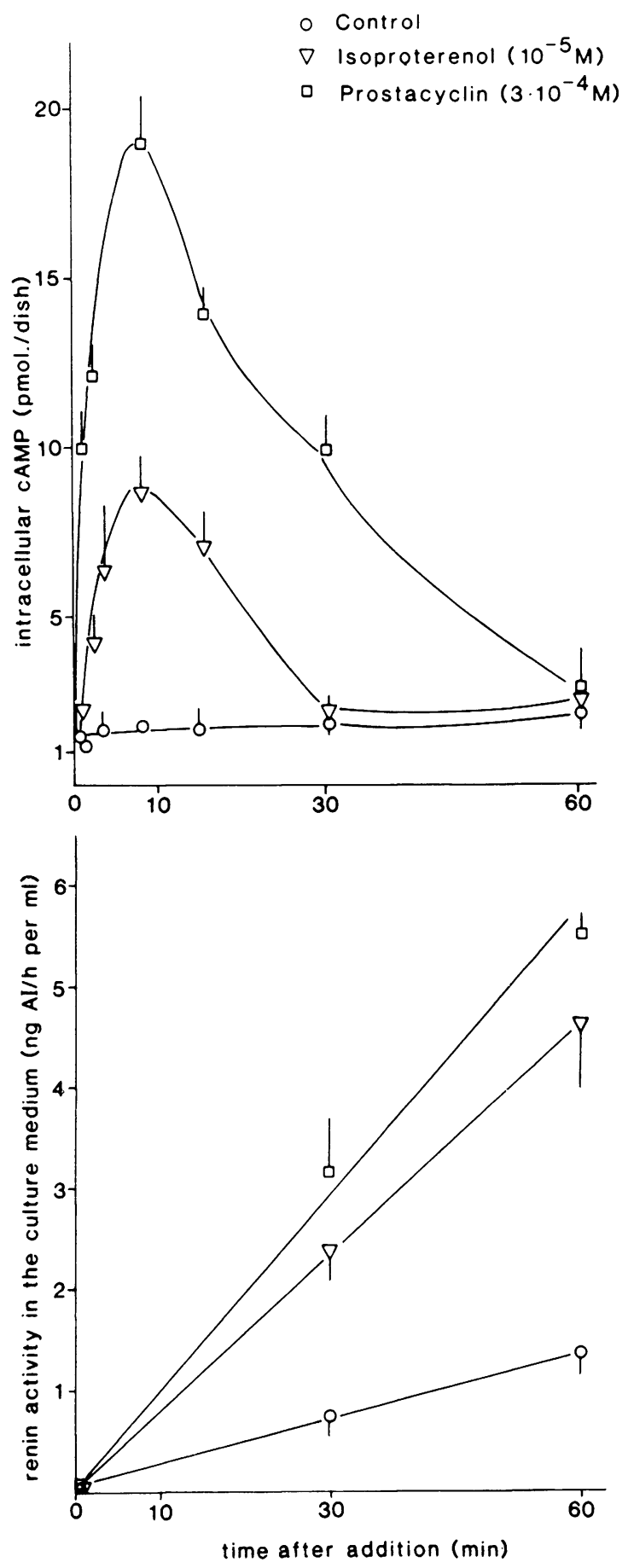
2. In experiments using isolated juxtaglomerular cells it was found that activators of adenylate cyclase decrease the calcium permeability of the plasma membrane (Kurtz et al. 1984).

3. It has been shown that the stimulatory effect of cAMP can be attenuated or even abolished by maneuvers which are expected to increase the intracellular concentration of calcium (Churchill and Churchill $1982 \mathrm{a}$; Opengorth and Zehr 1983; Vandongen 1975).

4. It has been found that cAMP is capable of stimulating calcium ATPase and the sodium-calcium exchange mechanism in a variety of cells (Phillis and Wu 1981; van Breemen et al. 1979), both processes are expected to cause a fall in the intracellular concentration of calcium. Altogether, there are good reasons to argue that cAMP and activators of adenylate cyclase may stimulate renin release by decreasing intracellular calcium activity.

\subsubsection{Role of $c G M P$}

Little information exists on the possible role of cGMP in the control of renin release. Recently, a hormone has been discovered that is thought to act on its target cells by increasing the intracellular level of cGMP. This hormone is the atrial natriuretic peptide (ANP) (Ballermann and Brenner 1985), and besides its natriuretic effect, it has also been found to inhibit renal renin release (Burnett et al. 1984; Garcia et al. 1985; Maack et al. 1985). It was not clear whether ANP exerts its effect by a direct action on juxtaglomerular cells, or indirectly by activating the macula densa mechanism; therefore, the effects of ANP, on renin release from renal cortical slices (Obana et al. 1985; Henrich et al. 1986; Takagi et al. 1988; Antonipillai et al. 1986) and from rat (Kurtz et al. 1986.b) and tumoral human juxtaglomerular cells (Pinet et al. 1987) were investigated. With the exception of one study (Tagaki et al. 1986), the results revealed that ANP leads to a dose-dependent inhibition of renin release from these preparations. ANP also caused enhanced release of cGMP and decreased release of cAMP from perfused kidney preparations (Obana et al. 1985).

The observation that ANP is capable of stimulating guanylate cyclase (Tremblay et al. 1985) and simultaneously inhibiting adenylate cyclase in the kidney (Anand-Srivasta et al. 1984) provoked the question of whether the inhibitory effect of ANP on renin release was due to the rise in cGMP or to the decrease in CAMP. Using isolated juxtaglomerular cells we obtained clear evidence that the inhibition of renin release by ANP correlates with the level of cGMP and not with the level of cAMP (Kurtz et al. 1986b). Moreover, we found that renin release from isolated juxtaglomerular cells is inversely related to the cellular level of cGMP. Pinet et al. (1987) also provided evidence that the inhibitory effect of ANP on renin release from human tumoral juxtaglomerular cells is not mediated by cAMP. From these findings it may be 
inferred that ANP inhibits renin release by raising the intracellular level of cGMP. This may indicate that cGMP is an inhibitory signal in the control of renin release in juxtaglomerular cells, a conclusion supported by the observation that renin release from renal cortical slices (Hirume et al. 1986) and isolated juxtaglomerular cells (Kurtz et al. 1986 b) is inhibited by nitroprusside, which is a well known activator of soluble guanylate cyclase. Recently, it was demonstrated that endothelium-derived relaxing factor, which acts by stimulating soluble guanylate cyclase, also inhibits renin release in vitro (Vidal et al. 1988). In addition, membrane-permeable cGMP analogs such as 8-bromo-cGMP have been found to inhibit renin secretion from renal cortical slices (Henrich et al. 1988; Hiruma et al. 1986) and isolated juxtaglomerular cells (Kurtz et al. 1988c).

As with cAMP, the question arises as to whether cGMP has a direct effect on the regulation of renin release or whether it acts indirectly by increasing the intracellular calcium concentration. Calcium measurements in single juxtaglomerular cells revealed that cGMP does not alter basal calcium levels and does not interfere with calcium mobilization. Moreover, it was shown that ANP, which is thought to act via cGMP, did not alter calcium-45 uptake into isolated juxtaglomerular cells. It is likely, therefore, that the inhibitory effect of cGMP on renal renin release does not involve an increase in the cytosolic calcium concentration. It should be noted that in studies using isolated juxtaglomerular cells the inhibitory effect of ANP on renin release was markedly attenuated in the presence of the calcium channel blocker, verapamil (Kurtz et al. $1986 \mathrm{c}$ ). Since verapamil decreases the basal calcium influx into the cells (Kurtz et al. 1984; 1986a), one could assume from these findings that cGMP requires a normal calcium concentration to exert its maximal inhibitory effect on renin release.

The available experimental evidence thus indicates that cGMP is an inhibitory signal for renin release from juxtaglomerular cells and that it does not affect intracellular calcium concentration.

\subsection{G Proteins}

The role of GTP-binding $(\mathrm{G})$ proteins in the control of exocytosis has gained increasing interest. In particular, three types of $G$ proteins are considered to be involved in the regulation of secretion:

1. A G protein, $G_{P}$, which couples cell surface receptors to PLC (Burgoyne 1987). This type of $G$ protein thus mediates receptor mediated calcium release and activation of protein kinase $C$.

2. A $G$ protein which is involved in secretion, $G_{E}$ (Burgoyne 1987), the existence of which has been inferred from experiments on mast cell secretion 
(Barrowman et al. 1986). The detailed mechanism of action of this G protein has not yet been elucidated.

3. A type of $G$ protein which recent findings (Axelrod et al. 1988) have suggested may mediate receptor-operated activation of phospholipase $\mathrm{A}_{2}$ $\left(\mathrm{PLA}_{2}\right)$ : some evidence indicates that $\mathrm{PLA}_{2}$ activity could also be involved in the regulation of secretion (Burgoyne et al. 1987).

So far only indirect evidence exists about the role of $\mathrm{G}$ proteins in the cellular regulation of renin secretion from juxtaglomerular cells. This evidence is based on results from experiments with pertussis toxin (PT), which is known to inhibit certain $\mathrm{G}$ proteins.

It has been found that PT enhances basal renin release in the intact organism (Pedraza-Chaveri et al. 1985), isolated perfused kidney (Hackenthal et al. 1987), renal cortical slices (Pedraza-Chaveri et al. 1986; Rossi et al. 1987), and isolated juxtaglomerular cells (Kurtz et al., unpublished). From these findings it may be inferred that PT-sensitive G proteins in juxtaglomerular cells act as inhibitory signals for renin secretion.

In addition, it was shown that PT blunted the inhibitory effects of angiotensin II (Hackenthal et al. 1985), noradrenergic agonists (PedrazaChaveri et al. 1986), neuropeptide Y (Hackenthal et al. 1987), and adenosine (Rossi et al. 1987) on renin secretion. It was speculated that these hormones all inhibit renin secretion via the $G$ protein which inhibits adenylate cyclase $\left(\mathrm{N}_{\mathrm{i}}\right)$, because this $\mathrm{G}$ protein is the classic target of PT (Murayama and Ui 1983). Moreover, blocking the inhibition of cAMP formation in juxtaglomerular cells could explain the observed stimulatory effect of PT on renin secretion. However, recent evidence indicates that PT is also capable of inhibiting $G$ proteins other than $\mathrm{N}_{\mathrm{i}}$ in a number of cell types (Axelrod et al. 1988). The calcium mobilizing effects of angiotensin II are mediated by $G$ proteins in juxtaglomerular cells (Kurtz and Penner 1989).

At this point, some attention should be paid to the role of PLA $\mathrm{P}_{2}$ activity in the control of renin secretion. Most of the conditions known to inhibit renin secretion are associated with a stimulation of $\mathrm{PLA}_{2}$ activity and vice versa. Specifically, vasoconstrictive hormones (Ardaillou et al. 1985) and elevation of intracellular calcium (Hassid 1982) are known to stimulate PLA activity and to inhibit renin secretion. In contrast, inhibition of $\mathrm{PLA}_{2}$ activity by low calcium, cAMP (Hassid 1982), calmodulin antagonists (Craven and De Rubertis 1983), and cyclosporin A (Kurtz et al. 1987) is associated with stimulation of renin secretion from juxtaglomerular cells (Kurtz et al. 1988 b). The possibility that PLA $_{2}$ plays an inhibitory role in renin secretion is supported by the recent findings that derivatives of arachidonic acid, which is liberated by $\mathrm{PLA}_{2}$ activity, are inhibitory for renin secretion (Antonipillai et al. 1987), and could mediate the inhibitory effect of angiotensin II on renin secretion (Antonipillai et al. 1988). 
In summary, there is indirect evidence that $G$ proteins play an inhibitory role in renin secretion. The nature of the $G$ proteins possibly involved in the regulation of renin secretion still has to be clarified.

\subsection{Membrane Potential}

Electrical processes are known to have an important function in the regulation of exocytosis from secretory cells (Petersen and Maruyama 1984; Penner 1988). Before discussing the possible involvement of ion channels in the regulation of renin secretion, the general electrical properties of juxtaglomerular cells should be considered. Microelectrode studies have revealed a rather negative membrane potential ranging from -60 to $-80 \mathrm{mV}$ (Fishman 1976; Bührle et al. 1985). These findings were confirmed by recent patch clamp studies on single juxtaglomerular cells (Kurtz and Penner 1989). The negative membrane potential results from an anomalous inward-rectifying potassium current (Kurtz and Penner 1989); this explains the strict dependence of the juxtoglomerular cell membrane potential on the extracellular concentration of potassium (Fishman 1976). In addition, a delayed rectifying potassium current which is activated upon depolarization was found. No evidence of voltage-gated sodium or calcium currents was obtained in the patch clamp study; however, the existence of large calcium-activated currents was documented (Fig. 6). This appears to be via calcium-activated chloride channels, which are directly regulated by the intracellular concentration of calcium within juxtaglomerular cells. It is tempting to speculate that these chloride channels are involved in the inhibition of renin secretion by calcium (see Sect. 4).

An increase in the extracellular concentration of potassium (Fishman 1976) and of the vasoconstrictive hormones angiotensin II, arginine-vasopressin, and norepinephrine (Bührle et al. 1986b) causes a significant depolarization of juxtaglomerular cells, and at the same time an inhibition of renin secretion (Churchill 1980; Bührle et al. 1986a,b). Due to the simultaneity of both events it was speculated that membrane depolarization is part of the mechanism by which vasoconstrictor hormones inhibit renin secretion. It has been shown that the inhibition of renin release by potassium depolarization and vasoconstrictive hormones can be significantly attenuated by calcium channel blockers (P.C. Churchill 1980; Kurtz et al. 1986a). Since membrane depolarization is the signal for the opening of voltage-dependent calcium channels, it was inferred that membrane depolarization leads to an inhibition of renin release by enhancing transmembrane calcium entry into the juxtaglomerular cells (P. C. Churchill 1980; Bührle et al. 1986b). This conclusion is apparently contradictory to the findings of patch clamp investigations, which did not provide evidence for the existence of voltage-gated calcium channels. However, the possibility that juxtaglomerular cells possess voltage-gated calcium 


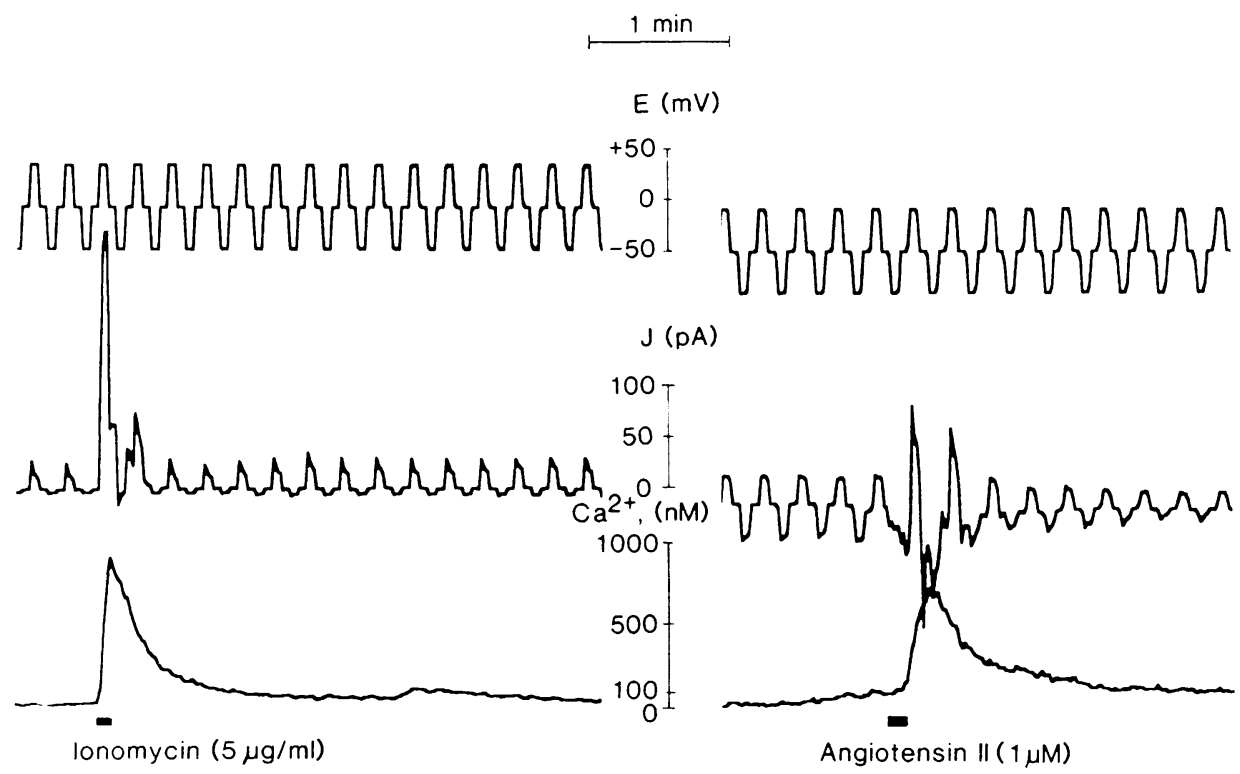

Fig. 6. Chloride currents in renal juxtaglomerular cells activated by increases in intracellular calcium evoked by ionomycin $(5 \mu \mathrm{g} / \mathrm{ml})$ and angiotensin II $(1 \mu M)$. $E$, membrane potential; $J$, current

channels with unusually fast run-down kinetics cannot be definitively ruled out as a result of the patch clamp study. This study, on the other hand, has confirmed that angiotensin II causes depolarization of juxtaglomerular cells, which most likely results from reversible inhibition of the anomalous inwardrectifying potassium current (Kurtz and Penner 1989).

The question of whether hyperpolarization of juxtaglomerular cells is a stimulatory signal for renin release cannot be answered yet. Fishman (1976) reported that epinephrine, which is known to stimulate renin secretion, induced a small hyperpolarization; however, this was not confirmed by the study of Bührle et al. (1986a,b), who observed that $\beta$-adrenergic compounds, which stimulate renin release, had no influence on the membrane potential of juxtaglomerular cells.

Recently, it was shown that Cromakalim, a drug which hyperpolarizes smooth muscle cells by the opening of certain potassium channels (Hamilton et al. 1986), stimulates renin secretion in humans in vivo and also in vitro from isolated rat renal juxtaglomerular cells (Ferrier et al. 1989). However, presently it is not known whether Cromakalim enhances renin secretion by causing membrane hyperpolarization in juxtaglomerular cells or by a different mechanism.

Overall, therefore, there are some indications that the electrical behavior of juxtaglomerular cells affects the exocytosis of renin. In particular, membrane 
depolarization could cause inhibition of renin secretion. Whether this phenomenon is mediated by voltage-gated calcium channels or by different mechanisms, such as $\mathrm{Na}^{+} / \mathrm{Ca}^{2+}$ exchange, needs to be clarified.

\subsection{Osmotic Forces}

Skott (1988) has recently reviewed in detail the possible role of osmotic forces in the exocytosis of renin. Changes in extracellular osmolarity are known to significantly alter exocytosis in a number of secretory cells. This behavior appears to be a rather uniform process, increase in extracellular osmolarity causing an inhibition of secretion and vice versa (see Skott 1988). Renin secretion from juxtaglomerular cells shows the same dependence in osmolarity (Skott and Taugner 1987); renin secretion appears to be very sensitive to rather small changes in osmolarity (Skott and Taugner 1987). Moreover, changes in renin secretion occurs only with a short delay after osmolarity changes.

It has been demonstrated that the nature of osmotically active particles is important for their effect on renin secretion, the effect on exocytosis is directly related to the reflection coefficient of the particle (Frederiksen et al. 1975). From this observation juxtaglomerular cells are assumed to behave as sensitive osmometers. The mechanism by which changes in extracellular osmolarity alter renin secretion from juxtaglomerular cells is not yet known, but cell volume may be an important control mechanism since it is possible that states of decreased cell volume inhibit exocytosis of renin, and vice versa (Skott 1988).

At this point it should be recalled that morphological evidence exists which shows that renin-containing granules swell before or during exocytosis (Taugner et al. 1984; Skott and Taugner 1987). If such a swelling is a prerequisite for exocytosis, then renin secretion would obviously depend on the availability of cytosolic water.

\section{Possible Explanations for the "Calcium Paradox"}

Having considered the influence of a number of intracellular parameters on renin secretion from juxtaglomerular cells, the question arises as to whether or not the individual findings allow the development of a more general concept of the cellular control of renin secretion. Although this is not entirely possible, some guidelines can be recognized. Thus, calcium appears as the dominant second messenger for renin secretion, while C kinase, cAMP, and cGMP either act via calcium, or at least require calcium to exert their effects. Calcium has an inhibitory and therefore "paradoxical", effect on secretion 


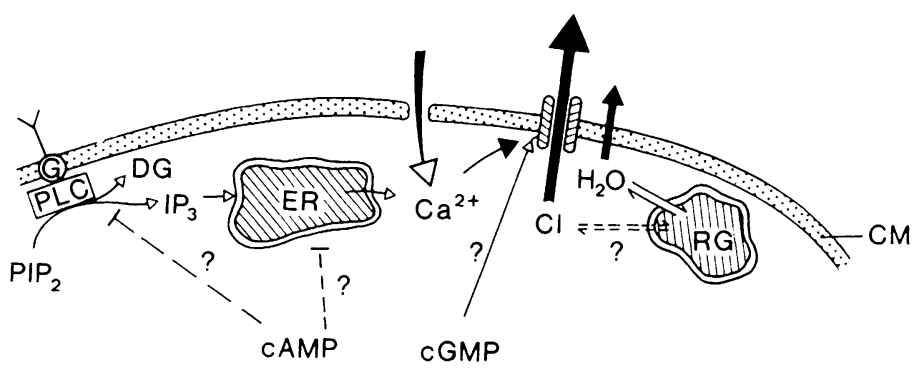

Fig. 7. Possible role of calcium-activated chloride channels in the regulation of renin secretion. $G$, GTP-binding protein; $P L C$, phospholipase C; $P I P_{2}$, phosphatidylinositol bisphosphate; $D G$, diacylglycerol; $I P_{3}$, inositol triphosphate; $E R$, endoplasmic reticulum; $R G$, renin granule; $C M$, cell membrane

from juxtaglomerular cells. Calcium in juxtaglomerular cells appears to be regulated by transmembrane influx, release from intracellular stores, calcium ATPase, and sodium/calcium exchange. Moreover, it seems that the calcium concentration just beneath the plasma membrane is more important for the regulation of renin secretion than the cytosolic calcium concentration. Based on this consideration some speculations have been made as to how calcium inhibits renin secretion.

Taugner et al. (1988) observed that the myofibrils in juxtaglomerular cells are displaced to a small subplasmalemmal border, and they developed the hypothesis that the calcium-dependent state of contraction of these myofilaments regulates the exocytosis; increased subplasmalemmal calcium concentration could cause myofilaments to form a shield between the granules and the plasma membrane, thus inhibiting exocytosis. This concept is compatible with the idea that the subplasmalemmal portion of the cytoskeleton has a general inhibitory function in secretion (Burgoyne et al. 1988). The concept could also explain the apparent stimulatory effect of cAMP on renin secretion, because cAMP is expected to inhibit the contraction of the myofibrils, both by inhibition of calcium mobilization and by inactivation of myosin light chain kinase (Adelstein 1983).

A different explanation as to how calcium could regulate renin secretion is based on the existence of calcium-activated chloride channels (Fig. 7). The activity of the chloride channels is directly regulated by the subplasmalemmal concentration of calcium. The sum conductance of these chloride channels is very large in juxtaglomerular cells (Kurtz and Penner 1989), and it can be assumed that the channels contribute significantly to the regulation of cell volume juxtaglomerular cells. Since the membrane potential in juxtaglomerular cells is close to the potassium equilibrium potential, and thus far more negative than the chloride equilibrium potential, a calcium-regulated chloride efflux from juxtaglomerular cells can be predicted. Chloride ions would be 
accompanied by potassium via voltage-gated inward-rectifying potassium channels. The efflux of potassium chloride would cause cell shrinkage and consequently a reduction in the cellular water content. As already mentioned, exocytosis of renin appears to require granule swelling by intragranular water influx (Taugner et al. 1984; Skott and Taugner 1987); thus a calcium-activated chloride and water efflux from juxtaglomerular cells would impede granule swelling. As a result, renin secretion would appear to be inversely related to intracellular calcium concentration. cAMP, on the other hand, inhibits increases of intracellular calcium and thus inhibits the activation of the chloride channels and cell shrinkage. Consequently, cAMP would blunt the inhibition of renin secretion. The inhibitory role of cGMP on secretion could also be explained by this concept.

Patch clamp investigations on juxtaglomerular cells have revealed that cGMP increases the calcium sensitivity of the chloride currents (Kurtz and Penner, unpublished). This is compatible with the observation that cGMP requires normal calcium concentrations for its optimal effect.

Finally, regulation of renin secretion by $\mathrm{PLA}_{2}$ is also conceivable. PLA 2 is located at the plasma membrane, and its activity is regulated by the subplasmalemmal concentration of calcium. As already mentioned, a possible inhibitory effect of $\mathrm{PLA}_{2}$ activity on renin secretion could be mediated by lipoxygenase products.

Discovering whether one or even all three hypotheses on the inhibitory action of calcium on the exocytosis of renin is correct remains a task for future research.

\section{Physiological Environment of Juxtaglomerular Cells}

As mentioned in the introduction, during the past 20 years four basic mechanisms for controlling renin release from the kidney under normal physiological conditions have been described (Davis and Freeman 1976). These are:

1. An intrarenal baroreceptor

2. The macula densa receptor

3. The sympathetic nervous system

4. Hormones

In the following sections on attempt is made to discuss the possible cellular mechanisms by which these four mechanisms could exert control over renal renin release. 


\subsection{Baroreceptor}

The existence of a baroreceptor which controls renin secretion has been inferred from the findings that the renal perfusion pressure significantly affects renal renin release (Davies and Freeman 1976; Keeton and Campbell 1981). An increase in perfusion pressure leads to a decrease in renin release, and a fall in perfusion pressure stimulates renin release.

The localization and mode of function of this baroreceptor have not yet been identified. Experimental observations and theoretical considerations led to the suggestion that the baroreceptor acts as a stretch receptor (Tobian 1960; Skinner et al. 1964; Fray 1980). If it is assumed that the baroreceptor is localized in the afferent arteriole with the juxtaglomerular cells, a search should be made for a mechanism by which stretch of the arteriolar wall could influence renin release from the juxtaglomerular cells. The idea that the juxtaglomerular cell itself could behave as a stretch receptor has recently been supported by the finding of Fray and Lush (1984) that isolated juxtaglomerular cells grown on elastic support respond to an increased stretch with a decreased rate of renin release. It has been pointed out that juxtaglomerular cells would be particulary suitable to act as mechanoreceptors because they are poor in contractile filaments and therefore are presumably neither involved in autoregulation nor in vasoconstriction (Taugner et al. 1984).

If stretch of the juxtaglomerular cell membrane does affect renin release, then the question arises as to how membrane stretch is translated into the intracellular regulation of renin secretion. The most convenient model for this signal transduction has been devised by Fray and coworkers, who suggest that stretch of the juxtaglomerular cell membrane influences renin secretion by altering the membrane potential of the cells (Fray and Lush 1984). This concept fits with a variety of results.

It has been found that smooth muscle cells respond to stretch with depolarization (Bühlbring 1955; Coburn 1987; Harder 1984; Harder et al. 1987). Since no difference in the electrical behavior between juxtaglomerular cells and smooth muscle cells has been observed so far, it could be inferred that juxtaglomerular cells also depolarize in response to stretch. Depolarization, however, has been found to be associated with inhibition of renin secretion (Churchill 1985). As already discussed, this inhibition of renin secretion by membrane depolarization could be mediated by voltage-activated calcium channels. Alternatively, stretch of ion channels could also directly increase the calcium permeability of the cell membrane (Kirber et al. 1988). It should be recalled that in isolated juxtaglomerular cells renin release is inversely related to the calcium conductance of the cell membrane (Kurtz et al. 1984).

The concept that the baroreceptor works by altering transmembrane calcium fluxes is supported by the observations that the inhibitory effect of pres- 
sure on renin release is directly related to the extracellular concentration of calcium (Fray et al. $1983 \mathrm{a}, \mathrm{b}$ ). In addition, calcium channel blockade prevents the inhibition of renin release by high pressure (Fray et al. $1983 \mathrm{a}, \mathrm{b}$ ).

The concept presented still needs to be proved experimentally. A suitable method of investigation could be patch clamp studies using single juxtaglomerular cells located in isolated afferent arterioles, in combination with single cell calcium measurement. Then it should be possible to detect stretchdependent changes in ion permeabilities and intracellular calcium concentrations.

Summing up, the mechanism of action of the baroreceptor has not been identified. Theoretically it could be explained by stretch-dependent alterations in the intracellular calcium activity of juxtaglomerular cells.

\subsection{Macula Densa}

The macula densa segment of the distal tubule is considered to have two important roles in renal function: first, to mediate a negative feedback mechanism between glomerular filtration and afferent arteriolar perfusion (tubuloglomerular feedback, TGF) and, secondly, to link renin release to dietary intake of sodium chloride (Briggs and Schnermann 1986).

It has been portulated that a receptor which "measures" the ionic composition of the tubular fluid in the late proximal tubule exists at the macula densa, of the distal tubule. In particular, the concentration of sodium chloride is an effective modulator of renin release from juxtaglomerular cells (Davis and Freeman 1976; Keeton and Campbell 1981); a high load of sodium chloride in the macula densa region suppresses renin release, whilst a low concentration stimulates renin release. The mechanism of signal transduction from the macula densa to the juxtaglomerular cells is still subject to discussion. There is growing evidence that mediation by TGF and the adaptation of renin release to sodium chloride intake by the macula densa of use the same signalling pathway (Briggs and Schnermann 1976).

Some evidence points towards the generation of a metabolic signal by the macula densa cells. Presently, it is thought that there are two ways by which macula densa cells could generate signals: either directly, by releasing a metabolite from energy metabolism, or indirectly by altering the sodium chloride concentration and the tonicity around juxtaglomerular cells.

The link between energy metabolism and the macula densa signal is considered initially. An increase in the load of sodium chloride to the early distal tubule leads to an enhanced rate of sodium chloride reabsorption. Since the reabsorption of sodium chloride is energy dependent, an increased load causes increased energy turnover in the tubular cells (Osswald et al. 1982), which in turn leads to an increased rate of hydrolysis of ATP, causing a rise 
in the level of adenosine (Osswald et al. 1982). Adenosine, which is released from cells (Miller et al. 1978), is known to be a renal vasoconstrictor and a potent inhibitor of renin release (Spielman and Thompson 1982; Skott and Baumbach 1985). Therefore, the concept has been developed that adenosine is the macula densa signal that mediates the inhibition of renin release from juxtaglomerular cells caused by an increased load of sodium chloride in the macula densa region (Osswald 1984). Recently, it has been shown by in vitro experiments that the macula densa significantly influences the response of juxtaglomerular cells to adenosine (Itoh et al. 1985 b).

If adenosine is the macula dense signal, the question arises of the mechanism by which it could inhibit renin release from the juxtaglomerular cells. Using incubated renal cortical slices it was shown that adenosine has a biphasic effect on the rate of renin release (Churchill and Churchill 1985). Low concentrations of adenosine inhibit renin release, with a nadir at $0.1 \mu M$. At concentrations higher than $10 \mu M$, adenosine was found to stimulate renin release from the slices. In a recent experiment using cultures of juxtaglomerular cells we also found an inhibitory effect of adenosine on renin release (Kurtz et al. 1988b). Since the stimulation of renin release was only observed with large, pharmacological doses of adenosine, studies should concentrate on the physiological concentration range of adenosine $(0.1-1 \mu M)$, in which a significant inhibition of renin release was observed (Churchill and Churchill 1985; Itoh et al. 1985 b; Kurtz et al. 1988 b). This inhibitory effect appears to be mediated by adenosine $A_{1}$ receptors, since it can be mimicked by specific adenosine $A_{1}$ agonists such as cyclohexyladenosine (CHA) (Murray and Churchill 1984; Churchill and Churchill 1985; Kurtz et al. 1988b). Using isolated juxtaglomerular cells we found that $0.1 \mu M$ adenosine influenced neither the transmembrane calcium influx nor the intracellular calcium level, as monitored by the fluorescence signal of the calcium indicator dye quin 2. At this concentration adenosine had no detectable effect on the cAMP level (Kurtz et al. 1988b), or on the membrane potential (Bührle et al. 1986b); however, we noted a concentration-dependent increase in the level of cGMP (Kurtz et al. 1988 b). Since there is evidence that a rise in the cytosolic concentration of cGMP inhibits the secretory process in the juxtaglomerular cells, it seems possible that adenosine inhibits renin release by raising cGMP levels.

Another method by which the macula densa could generate signals is conceivable. Recently it has been shown that renin release from isolated juxtaglomerular apparatuses is inversely related to the sodium chloride concentration at the corresponding macula densa (Skott and Briggs 1987). Increased sodium chloride concentration in the tubular fluid results in an increased furosemide-sensitive transtubular sodium chloride transport to the interstitial space between the macula densa and the juxtaglomerular cells (Gonzalez et al. 1988). Since this space is not well drained, the local sodium chloride concentration changes in relation to the tubular sodium chloride load (Gonzalez 
et al. 1988; Persson et al. 1988). Juxtaglomerular cells have been found to behave as sensitive osmometers and an increase in extracellular tonicity causes inhibition of renin release and vice versa (Frederiksson et al. 1975; Skott 1988). However, this concept cannot yet explain the vasoconstricting effect of the macula densa signal.

\subsection{Sympathetic Nervous System}

It is well known that activation of the sympathetic nerves in the kidney leads to a rise in the rate of renin release (Davis and Freeman 1976; Keeton and Campbell 1981). The action of the sympathetic nervous system on renin secretion requires functioning $\beta$-adrenergic receptors (Taher et al. 1976), the existence of which has been demonstrated in the juxtaglomerular region (Atlas et al. 1977). Since $\beta$-adrenergic receptors are known to be coupled with adenylate cyclase in a stimulatory fashion, it can be inferred that the sympathetic nervous system stimulates renin release by raising the cellular cAMP level. In fact, in isolated rat renal juxtaglomerular cells, it has been shown that the $\beta$ adrenergic agonist isoproterenol raises intracellular cAMP (Kurtz et al. 1984). As discussed above, cAMP presumably enhances the rate of renin release either by a direct effect or by lowering the intracellular activity of calcium.

It may, at first, seem remarkable that stimulation of renal sympathetic nerves leads to stimulation of renal renin release. The dominant transmitter of the peripheral sympathetic nervous system is norepinephrine, which is known to be a calcium mobilizing hormone for various cells, acting via $\alpha_{1}$-adrenoreceptors (Berridge and Irvine 1984). We have found that $10^{-5} \mathrm{M}$ norepinephrine enhances transmembrane calcium influx and inhibits renin release from cultured juxtaglomerular cells (Kurtz et al. 1986a). $10^{-5} M$ norepinephrine was also found to inhibit renin release from renal cortical slices (Capponi and Valloton 1976) and isolated perfused kidneys (Logan and Chatzillias 1980; Opengorth and Zehr 1983). However, it has been shown that norepinephrine at concentrations lower than $10^{-5} M$ results in stimulation of renin release, which is mediated via $\beta$-receptors (Lopez et al. 1978). We may assume, therefore, that norepinephrine is released from sympathetic nerve terminals at concentrations which stimulate renin release via $\beta$-receptors.

\subsection{Hormones}

To date a number of hormones have been tested as to their effects on renal renin release. In this review we are only considering those hormones for which there is evidence that they act directly on juxtaglomerular cells. These hor- 
Table 1. Hormones stimulating renin release

\begin{tabular}{ll}
\hline Hormone & Reference \\
\hline$\beta$-Adrenergic agonists & Keeton and Campbell 1981 \\
Dopamine & Kurtz et al. 1988d \\
Prostaglandin $E_{2}$ & Keeton and Campbell 1981 \\
Prostaglandin I 2 & Keeton and Campbell 1981 \\
Glucagon & Keeton and Campbell 1981 \\
Parathyroid hormone & Keeton and Campbell 1981 \\
Vasoactive intestinal peptide & Porter et al. 1983 \\
Calcitonin gene-related peptide & Kurtz et al. 1988c \\
\hline
\end{tabular}

Table 2. Hormones inhibiting renin release

\begin{tabular}{ll}
\hline Hormone & Reference \\
\hline Angiotensin II & Keeton and Campbell 1981 \\
Arginine-vasopressin & Keeton and Campbell 1981 \\
$\alpha$-Adrenergic agonists & Keeton and Campbell 1981 \\
Platelet-activating factor & Pfeilschifter et al. 1985 \\
Neuropeptide Y & Hackenthal et al. 1987 \\
Adenosine & P.C. Churchill and M. C. Churchill 1985 \\
Atrial natriuretic peptide & Kurtz et al. 1986b \\
\hline
\end{tabular}

mones are classified according to their ability to either stimulate (see Table 1) or inhibit renin release (see Table 2).

Hormones which stimulate renin release such as $\beta$-adrenergic agonists, dopamine, prostaglandins $E_{2}$ and $I_{2}$ glucagon, parathyroid hormone, vasoactive intestinal peptide, and calcitonin gene-related peptide (CGRP) have been shown to activate adenylate cyclase in various cell types. It may be inferred, therefore, that these hormones also activate adenylate cyclase in juxtaglomerular cells, and consequently cause a rise in the cytosolic level of cAMP. In our studies we have demonstrated that isoproterenol, prostaglandin $\mathrm{I}_{2}$, and CGRP elevate the intracellular concentrations of cAMP in isolated juxtaglomerular cells (Kurtz et al. 1984, 1988 c). Since cAMP is a stimulatory signal for renin release it may be concluded that these hormones stimulate renin release from juxtaglomerular cells via a rise in cAMP induced by stimulation of adenylate cyclase.

The hormones listed in Table 2 which have been found to inhibit renin release can be separated into two classes. One of the classes is composed of hormones which are known to mobilize calcium and which presumably inhibit renin release by increasing the intracellular concentration of calcium. These hormones also activate PLC in various cells. This group of hormones includes 
all vasoconstrictors, e.g., angiotensin II, arginine-vasopressin, norepinephrine, and platelet activating factor. We have shown that these hormones enhance the transmembrane calcium influx into the cells and lead to a rise in the cytosolic level of calcium (Kurtz et al. 1986a; Kurtz and Penner 1989).

Inhibition of the adenylate cyclase is considered as a possible mechanism by which neuropeptide Y (Hackenthal et al. 1987) and adenosine (Rossi et al. 1987) inhibit renin secretion. However, it is also conceivable that adenosine inhibits renin release by raising intracellular cGMP (Kurtz et al. $1988 \mathrm{a}$ ). This also appears to be the pathway along which atrial natriuretic peptide inhibits renin secretion.

\section{Conclusions}

In this review, present knowledge of the cellular regulation of renin secretion from renal juxtaglomerular cells has been considered. It appears that calcium is the dominant intracellular regulator of renin secretion and that it acts by inhibiting exocytosis. How calcium exerts this effect is not yet clear, but contraction of myofilaments, opening of chloride channels, and activation of $\mathrm{PLA}_{2}$ could be involved. C-kinase activation and cGMP seem to have an additional inhibitory effect on renin secretion, both in a calcium-dependent fashion. cAMP, on the other hand, stimulates secretion, presumably by decreasing intracellular calcium activity. GTP-binding proteins and electrical properties also seem to be involved in the control of renin secretion.

Present knowledge suggests that exocytosis in renal juxtaglomerular cells is regulated by mechanisms which differ from those of other secretory cells, where calcium and $\mathrm{C}$ kinase stimulate exocytosis. Revealing the reason for this unusual behavior remains a thrilling task for future research.

Acknowledgements. The author wishes to thank Dr. Rainer Nobiling for helpful comments in the preparation of this review. The artwork was done by W. Gehret. This work was supported by a grant from the Swiss National Science Foundation (grant 3.600-0.86).

\section{References}

Abe Y, Yukimara T, Iwao H, Mori N, Yamamoto K (1983) Effects of EDTA and Verapamil on renin release in dogs. Jpn J Pharmacol 33:627-633

Adelstein RS (1983) Regulation of contractile proteins by phosphorylation. J Clin Invest 72:1863-1866

Alkon DL, Rasmussen H (1988) A spatial-temporal model of cell activation. Science 239:998-1005 
Anand-Srivasta MB, Franks DJ, Cantin M, Genest J (1984) Atrial natriuretic factor inhibits adenylate cyclase activity. Biochem Biophys Res Commun 121:855-862

Antonipillai I, Horton R (1985) Role of extra- and intracellular calcium and calmodulin in renin release from rat kidney. Endocrinology 117:601-606

Antonipillai I, Nadler JL, Robon EC, Horton R (1977) The inhibitory role of 12- and 15-lipoxygenase products on renin release. Hypertension 10:61-66

Antonipillai I, Vogelsang J, Horton R (1986) Role of atrial natriuretic factor in renin release. Endocrinology 119:318-322

Antonipillai I, Nadler J, Horton R (1988) Angiotensin feedback inhibition on renin is expressed via the lipoxygenase pathway. Endocrinology 122:1277-1281

Ardaillou N, Hagege J, Nivez MP, Ardaillou R, Schlondorff D (1985) Vasoconstrictor-evoked prostaglandin synthesis in cultured human mesangial cells. Am J Physiol 248:F240-F246

Atlas D, Melamed E, Lahav M (1977) Beta-adrenergic receptors in rat kidney. Lab Invest 36:464-468

Axelrod J, Burch RM, Jelsema CL (1988) Receptor-mediated activation of phospholipase $\mathrm{A}_{2}$ via GTP-binding proteins: arachidonic acid and its metabolites as second messengers. Trends Neurosci 11:117-123

Baker PF (1976) The regulation of intracellular calcium. In: Duncan CJ (ed) Calcium in biological systems. Cambridge University Press, Cambridge, p 485

Ballermann BJ, Brenner BB (1985) Biologically active atrial peptides. J Clin Invest 76:2041-2048

Barajas L (1979) Anatomy of the juxtaglomerular apparatus. Am J Physiol 236:F333-F343

Barajas L (1986) The development and ultrastructure of the juxtaglomerular cell granule. J Ultrastruct Res 15:400-413

Barajas L, Powers K (1984) The structure of the juxtaglomerular apparatus (JGA) and the control of renin secretion: an update. J Hypertens 2 [Suppl 1]:3-12

Barrowman MM, Cockcroft S, Gomperts BD (1986) Two roles for guanine nucleotides in the stimulus-secretion sequence of neutrophils. Nature 319:504-507

Berridge MJ (1984) Inositoltriphosphate and diacylglycerol as second messengers. Biochem $J$ $220: 345-360$

Berridge MJ (1987) Inositoltriphosphate and diacylglycerol; two interactive second messengers. Annu Rev Biochem 56:159-193

Berridge MJ, Irvine RF (1984) Inositoltrisphosphate, a novel second messenger in cellular signal transduction: Nature 312:315-321

Blaustein MP (1974) The interrelationship between sodium and calcium fluxes across cell membrane. Rev Physiol Biochem Exp Pharmacol 70:33-80

Blendstrup K, Leyssac PP, Poulsen K, Skinner SL (1975) Characteristics of renin release from isolated superfused glomeruli in vitro. J Physiol (Lond) 246:653-672

Boyd AE (1982) Cytosceletal proteins and insulin secretion. In: Conn PM (ed) Cellular regulation of secretion and release. Academic, New York, pp 223-263

Briggs JP, Schnermann J (1986) Macula densa control of renin secretion and glomerular vascular tone: evidence for common cellular mechanisms. Renal Physiol 9:193-203

Bührle CP, Nobiling R, Taugner R (1985) Intracellular recordings from renin-positive cells of the afferent glomerular arteriole. Am J Physiol 249:F272-F281

Bührle CP, Hackenthal E, Helmchen U, Lackner K, Nobiling R, Steinhausen M, Taugner R (1986a) The hydronephrotic kidney of the mouse as a tool for intravital microscopy and in vitro electrophysiological studies of renin-containing cells. Lab Invest 54:462-471

Bührle CP, Scholz H, Hackenthal E, Nobiling R, Taugner R (1986b) Epitheloid cells: membrane potential changes induced by substances influencing renin secretion. Mol Cell Endocrinol 45:37- 47

Bülbring E (1955) Correlation between membrane potential, spike discharge and tension in smooth muscle. J Physiol 128:200-221

Burgoyne RD (1987) Control of exocytosis. Nature 328:112-113 
Burgoyne RD, Cheek TR, O'Sullivan AJ (1987) Receptor-activation of phospholipase $A_{2}$ in cellular signalling (1987) Trends Biochem Sci 12:332-333

Burgoyne RD, Cheek TR, O'Sullivan AJ, Richards RC (1988) Control of the cytosceleton during secretion. In: Thorn NA, Treimann M, Petersen OH (eds) Molecular mechanisms in secretion. Munksgaard, Copenhagen, pp 612-627

Burnett JC, Granijer JP, Opengorth TS (1984) Effects of synthetic atrial natriuretic factor on renal function and renin release. Am J Physiol 247:F863-F867

Burnham CE, Hawelu-Johnson CL, Frank BM, Lynch KR (1987) Molecular cloning of rat cDNA and its gene. Proc Natl Acad Sci USA 84:5605-5609

Campbell DJ (1987) Circulating and tissue angiotensin systems. J Clin Invest 79:1-6

Cantanzaro DF, Mullins JJ, Morris BJ (1983) The biosynthetic pathway of renin in mouse submandibular gland. J Biol Chem 258: 7364-87368

Capponi AM, Valloton MB (1976) Renin release by rat kidney slices incubated in vitro. Role of sodium and of $\alpha$ - and $\beta$-adrenergic receptors and effect of vincristine. Circ Res 39:200-203

Castagna M, Takai Y, Kaibuchi K, Sano K, Kikkawa U, Nishizuka Y (1982) Direct activation of calcium activated phospholipid dependent protein kinase by tumor promoting phorbol esters. J Biol Chem 251:7847-7851

Churchill MC, Churchill PC, McDonald FD (1983) Comparison of the effects of rubidium and potassium on renin secretion from rat kidneys slices. Endocrinology 112:777-781

Churchill PC (1979) Possible mechanism of the inhibitory effect of ouabain on renin secretion from rat renal cortical slices. J Physiol (Lond) 294:123-134

Churchill PC (1980) Effect of D-600 on inhibition of in vitro renin release in the rat by high extracellular potassium and angiotensin II. J Physiol (Lond) 304:449-458

Churchill PC (1981) Calcium dependency of the inhibitory effect of antidiuretic hormone on in vitro renin secretion in rats. J Physiol (Lond) 315:21-30

Churchill PC (1985) Second messengers in renin secretion. Am J Physiol 249:F175-F1984

Churchill PC, Churchill MC (1980) Vanadate inhibits renin secretion from rat kidney slices. J Pharmacol Exp Ther 213:144-149

Churchill PC, Churchill MC (1982a) Isoproterenol stimulated renin secretion in the rat: second messenger roles of $\mathrm{Ca}$ and cyclic AMP. Life Sci 30:1313-1319

Churchill PC, Churchill MC (1982b) Ca-dependence of the inhibitory effect of K-depolarization on renin secretion from rat kidney slices. Arch Int Pharmacodyn Ther 258:300-312

Churchill PC, Churchill MC (1983) Effects of trifluoperazine on renin secretion of rat kidneys slices. J Pharmacol Exp Ther 224:68-72

Churchill PC, Churchill MC (1984) 12-O-tetradecanoylphorbol-13-acetate (TPA) inhibits renin secretion of rat renal cortical slices. J Hyptertens 2[Suppl 1]:25-28

Churchill PC, Churchill MC (1985) $\mathrm{A}_{1}$ and $\mathrm{A}_{2}$ adenosine receptor activation inhibits and stimulates renin secretion of rat renal cortical slices. J Pharmacol Ther 232:589-594

Churchill PC, Churchill MC (1987) Bay K, a calcium channel antagonist, inhibits renin secretion in vitro. Arch Int Pharmacodyn Ther 285:87-97

Churchill PC, McDonald FD, Churchill MC (1981) Effect of diltiazem a calcium antagonist on renin secretion from rat kidney slices. Life Sci 29:383-389

Coburn RF (1987) Stretch induced membrane depolarization in ferret trachealis smooth muscle cells. J Appl Physiol 62:2320-2325

Craven PA, De Rubertis FR (1983) $\mathrm{Ca}^{2+}$ calmodulin-dependent release of arachidonic acid for renal medullary prostaglandin synthesis. J Biol Chem 258:4814-4823

Cruz-Soto M, Benabe JC, Lopez-Novoa JM, Martinez-Maldonado M (1984) $\mathrm{Na}^{+}-\mathrm{K}^{+}$-ATPase inhibitors and renin release: relationship to calcium. Am J Physiol 247:F650-F655

Davis JO, Freeman RH (1976) Mechanisms regulating renin release. Physiol Rev 56:1-56

De Duve C (1983) Lysosomes revisited. Eur J Biochem 137:391 - 397

Dzau VJ, Burt DW, Pratt RE (1988) Molecular biology of the renin-angiotensin system. Am J Physiol 255:F563-F573 
Ferrier C, Kurtz A, Lehner P, Shaw SG, Pusterla C, Saxenhofer H, Weidmann P (1989) Stimulation of renin secretion by potassium channel activation. Eur J Pharmacol 36:443-447

Fisher ER (1966) Lysosomal nature of juxtaglomerular granules. Science 152:1752-1753

Fishman MC (1976) Membrane potential of juxtaglomerular cells. Nature 260:542-544

Flynn M, Onomakpone N, Pearts WS (1977) The effects of ionophores (A 23187 and $\mathrm{RO}_{2}-2985$ ) on renin secretion and renal vasoconstriction. Proc $\mathrm{R}$ Soc Lond [Biol] 199:199-212

Fray JCS (1977) Stimulation of renin release in perfused kidney by low calcium and high magnesium. Am J Physiol 232:F377-F382

Fray JCS (1980) Stimulus secretion coupling of renin: role of hemodynamics and other factors. Circ Res 47:485-492

Fray JCS, Lush DJ (1984) Stretch receptor hypothesis for renin secretion: the role of calcium. J Hypertens 2 [Suppl 1]:19-23

Fray JCS, Park CS (1979) Influence of potassium, sodium, perfusion pressure and isoprenaline on renin release induced by calcium deprivation. J Physiol (Lond) 292:363-372

Fray JCS, Lush DJ, Valentine AND (1983 a) Cellular mechanism of renin release. Fed Proc 42:3150-3154

Fray JCS, Lush DJ, Share D, Valentine AND (1983 b) Possible role of calmodulin in renin secretion from isolated rat kidneys and renal cells: studies with trifluoperazine. J Physiol (Lond) $343: 447-454$

Frederiksen O, Leyssac PP, Skinner SL (1975) Sensitive osmometer function of juxtaglomerular cells in vitro. J Physiol (Lond) 252:669-679

Fukamizu A, Nishi K, Cho T, Saitoh M, Nakayama K, Ohkubo H, Nakanishi S, Murakami K (1988) Structure of the rat renin gene. J Mol Biol 201:443-450

Galen FX, Devaux C, Honot AM, Menard J, Corvol P, Corvol MT, Gubler MC, Mounier F, Camilleri JP (1984) Renin biosynthesis by human tumoral juxtaglomerular cells: evidences for a renin precursor. J Clin Invest 73:1144-1155

Garcia R, Thibault G, Gutkowska J, Hamet P, Cantin M, Genest J (1985) Effect of chronic infusion of synthetic atrial natriuretic factor (ANF 8-33) in conscious two-kidney, one-clip hypertensive rats. Proc Soc Exp Biol Med 178:155-159

Garrison JC (1983) Role of $\mathrm{Ca}^{2+}$-dependent protein kinase in the response of hepatocytes to $\alpha_{1}$-agonist, angiotensin II and suppressants. In: Harris RA, Cornell NW (eds) Isolation, characterization and use of hepatocytes. Elsevier, Amsterdam, pp 551-559

Gerber JG, Branch RA, Nies AS, Gerkens JF, Shand DG, Hollifield J; Oates JA (1978) Prostaglandins and renin release. II. Assessment of renin secretion following infusion of PG $\mathrm{I}_{2}$, $\mathrm{F}_{2 \alpha}$, and $\mathrm{D}_{2}$ into the renal artery of anesthetized dogs. Prostaglandins 15:81-88

Ginesi LM, Munday KA, Noble AR (1981) Active and inactive renin release by rabbit kidney cortex slices: effect of calcium and potassium. J Physiol (Lond) 315:41P-42P

Gomba S, Soltesz MB (1969) Histochemistry of lysosomal enzymes in juxtaglomerular cells. Experientia 25:513

Gonzalez E, Salomonsson M, Müller-Suur C, Persson AE (1988) Measurements of macula densa cell volume changes in isolated and perfused rabbit cortical thick ascending limb. II. Apical and basolateral cell osmotic water permeabilities. Acta Physiol Scand 133:159-166

Hackenthal E, Schwertschlag U, Hackenthal R (1978) The influence of vinblastine and colchicine on renin secretion in vivo and in vitro. Klin Wochenschr 56[Suppl I]:61-66

Hackenthal E, Schwertschlag U, Seyberter HW (1980) Prostaglandins and renin release. Studies in the isolated perfused kidney. Prog Biochem Pharmacol 17:98-107

Hackenthal E, Schwertschlag U, Taugner R (1983) Cellular mechanisms of renin release. Hypertension 5:975-993

Hackenthal E, Aktories K, Jakobs KH (1985) Pertussis toxin attenuates angiotensin II-induced vasoconstriction and inhibition of renin release. Mol Cell Endocrinol 42:113-117

Hackenthal E, Aktories K, Jakobs KH, Lang RE (1987) Neuropeptide Y inhibits renin release by a pertussis-toxin sensitive mechanism. Am J Physiol 252:F543-550 
Hall PF (1982) The role of the cytosceleton in endocrine function. In: Conn PM (ed) Cellular regulation of secretion and release. Academic, New York, pp 195-222

Hamilton TC, Weir SW, Weston AH (1986) Comparison of the effects of BRL 34915 and verapamil on electrical and mechanical activity in rat portal vein. $\mathrm{Br} \mathrm{J}$ Pharmacol $88: 103-111$

Harada E, Rubin RP (1978) Stimulation of renin secretion and calcium efflux from the isolated perfused cat kidney by norepinephrine after calcium deprivation. J Physiol (Lond) 249:367-379

Harder DR (1984) Pressure dependent membrane depolarization in cat middle cerebral artery. Circ Res 55:197-202

Harder DR, Gilbert R, Lambard JH (1987) Vascular muscle cell depolarization and activation in renal arteries an elevation of transmural pressure. Am J Physiol 253:F778-F781

Hardman JA, Hort YJ, Cantazaro DF et al. (1984) Primary structure of the human renin gene. DNA 3:457-468

Hassid A (1982) Regulation of prostaglandin biosynthesis in cultured cells. Am J Physiol 243:C205-C211

Henrich WL, Needleman P, Campbell WB (1986) Effect of Atriopeptin II on renin release in vitro. Life Sci 39:993-1001

Henrich WL, McAllister EA, Smith PB, Campbell WB (1988) Cyclic guanosine monophosphate as an intracellular mediator of the inhibition of renin release by atriopeptin and nitroprusside. Am J Physiol 255:F474-F479

Hillman-Rauch (1975) Lipidosis-like renal changes in rats treated with chlorphentermine or with tricyclic antidepressants. Virchows Arch B 18:51-60

Hiruma M, Ikemoto F, Yamamoto K (1986) Rat atrial natriuretic factor stimulates renin release from renal cortical slices. Eur J Pharmacol 125:151-153

Hoffstein S, Weissmann G (1978) Microfilaments and microtubules in calcium ionophore-induced secretion of lysosomal enzymes from human polymorphnuclear leukocytes. J Cell Biol 78:769-781

Horbart PM, Fogliano M, O Coonor BA, Schaefer IM, Chirgwin JM (1984) Human renin gene: structure and sequence analysis. Proc Natl Acad Sci USA 81:5026-5030

Houban Z, Slesers A, Hopkins E (1972) Drug induced and naturally occurring myeloid bodies. Lab Invest 27:62-70

Imai T, Miyazaki H, Hirose $\mathrm{S}$ et al. (1983) Cloning and sequence analysis of cDNA for human renin precursor. Proc Natl Acad Sci USA 80:7405-7409

Itoh S, Carretero OA, Murray RD (1985a) Renin release from isolated afferent arterioles. Kidney Int 27:762-767

Itoh S, Carretero OA, Murray RD (1985 b) Possible role of adenosine in the macula densa mechanism of renin release in rabbits. J Clin Invest 76:1412-1417

Iwao H, Abe Y, Yamamoto K (1974) Effect of intrarenal arterial infusion of calcium on renin release in dogs. Jpn J Pharmacol 24:482-484

Johns DW, Carey RM, Gomez RA, Lynch K, Inagami T, Saye J, Geray K, Farnsworht DE, Peach MJ (1987) Isolation of renin-rich rat kidney cells. Hypertension 10:488-496

Kawamura M, Inagami T (1983) Calmodulin antagonists stimulate renin release from isolated rat glomeruli. Endocrinology 112:1857-1859

Keeton TK, Campbell WB (1981) The pharmacologic alteration of renin release. Pharmacol Rev $31: 81-227$

Khayat A, Gonda S, Sen S, Smeby RR (1981) Responses of juxtaglomerular cell suspension to various stimuli. Hypertension 3:157-167

Kirber MT, Walsh JV, Singer JJ (1988) Stretch activated ion channels in smooth muscle: a mechanism for the imitation of stretch-induced contraction. Pflügers Arch 412:339-345

Kisch ES, Dluhy RG, Williams GH (1976) Regulation of renin release by calcium and ammonium ions in normal man. J Clin Endocrinol Metab 43:1343-1350

Kotchen TA, Maull KJ, Luke RG (1977) Effect of calcium gluconate infusion on renin in the dog. J Lab Clin Med 89:359-366 
Kurtz A, Penner R (1989) Angiotensin II induces oscillations of intracellular calcium and inhibits anomalous inward rectifying potassium current in renal juxtaglomerular cells. Proc Natl Acad Sci USA 86:3423-3427

Kurtz A, Pfeilschifter J, Bauer C (1984) Is renin secretion governed by the calcium permeability of the juxtaglomerular cell membrane? Biochem Biophys Res Commun 124:359-366

Kurtz A, Pfeilschifter J, Hutter A, Bührle CP, Nobiling R, Taugner R, Hackenthal E, Bauer C (1986a) Role of protein kinase $C$ in vasoconstrictor caused inhibition of renin release from isolated juxtaglomerular cells. Am J Physiol 250:C563-C571

Kurtz A, Della Bruna R, Pfeilschifter J, Taugner R, Bauer C (1986b) Atrial natriuretic peptide inhibits renin release from isolated renal juxtaglomerular cells by cGMP-mediated process. Proc Natl Acad Sci USA 83:4769-4773

Kurtz A, Della Bruna R, Pfleischifter J, Bauer C (1986c) Effect of synthetic atrial natriuretic peptide on rat renal juxtaglomerular cells. J Hypertens 4:S57-S60

Kurtz A, Pfeilschifter J, Kühn K, Koch KM (1987) Cyclosporine A inhibits PGE 2 release from vascular smooth muscle cells. Biochem Biophys Res Commun 147:542 - 549

Kurtz A, Della Bruna R, Kühn K (1988a) Cyclosporine A enhances renin secretion and production in isolated juxtaglomerular cells. Kidney Int 33:947-953

Kurtz A, Della Bruna R, Pfeilschifter J, Bauer C (1988 b) Role of cGMP as second messenger of adenosine in the inhibition of renin release. Kidney Int 33:798-803

Kurtz A, Muff R, Born W, Lundberg JM, Millberg BI, Gnädiger MP, Uehlinger DE, Weidmann P, Hökfelt T, Fischer JA (1988c) Calcitonin gene-related peptide is a stimulator of renin secretion. J Clin Invest 82:538-543

Kurtz A, Della Bruna K, Platz J, Cavero J (1988 d) Rat juxtaglomerular cells are endowed with DA-1 dopamine receptors mediating renin release. J Cardiovasc Pharmacol 12:658-663

Lacy PSD, Howell L, Young DS, Fink CJ (1968) New hypothesis of insulin secretion. Nature 219:1177-1179

Lester GE, Rubin RP (1977) The role of calcium in renin secretion from the isolated perfused cat kidney. J Physiol (Lond) 269:93-108

Logan AG, Chatzillias A (1980) The role of calcium in the control of renin release from the isolated rat kidney. Can J Physiol Pharmacol 58:60-66

Lopez GA, Reid IA, Rose JC, Ganong WF (1978) Effect of norepinephrine on renin release and cAMP content of rat kidney slices: modification by sodium deficiency and alpha-adrenergic blockade. Neuroendocrinology 27:63-73

Lopez-Novoa JM, Garcia JC, Cruz-Soto MA; Benabe JE, Martinez-Maldonado M (1982) Effect of sodium orthovanadate on renal renin secretion in vivo. J Pharmacol Exp Ther 222:447-451

Lyons HJ, Churchill PC (1974) The influence of ouabain on in vitro renin secretion. Proc Soc Exp Biol Med 145:1148-1150

Lyons HJ, Churchill PC (1975) Renin secretion from rat renal cortical cell suspensions. Am J Physiol 228:1835-1839

Maack T, Marion DN, Camargo MJF, Kleinert HD, Laragh JH, Vaughan ED, Atlas SA (1985) Effects of auriculin (atrial natriuretic factor) on blood pressure, renal function and the reninaldosteron system in dogs. Am J Med 77:1069-1075

Matsumara Y, Miyawaki N, Morimoto S (1984) Effects of W-7 and W-5 on renin release from rat kidney cortical slices. Jpn J Pharmacol 36:268-271

Matsuoka H, Ishii M, Sugimoto T, Hirata Y, Sugimoto T, Kangawa K, Matsuo H (1985) Inhibition of aldosterone production by $\alpha$-human atrial natriuretic polypeptide is associated with an increase in cGMP production. Biochem Biophys Res Commun 127:1052-1056

Miller WL, Thomas RA, Berne RM, Rubio R (1978) Adenosine production in the ischemic kidney. Circ Res 43:390-397

Moffet RB, McGowa RA, Gross KW (1986) Modulation of kidney renin messenger RNA levels during experimentally induced hypertension. Hypertension 8:874-882

Morimoto S, Yamamoto K, Horiuchi K, Tanaka H, Ueda J (1970) A release of renin from dog kidney cortex slices. Jpn J Pharmacol 20:536-545 
Morimoto S, Abe R, Fukuhara A, Tanaka K, Yamamoto K (1979) Effect of sodium restriction on plasma renin activity and renin granules in rat kidney. Am J Physiol 237:F367-F371

Murayama T, Ui M (1983) Loss of the inhibitory function of the guanine nucleotide regulatory component of adenylate cyclase due to its ADP ribosylation by islet activating protein, pertussis toxin, in adipocyte membranes. J Biol Chem 258:3319-3326

Murray RD, Churchill PC (1984) The concentration dependency of the renal vascular and renin secretory responses to adenosine receptor agonists. J Pharmacol Exp Ther 232:189-193

Nakamura N, Soubrier F, Menard J, Panthier JJ, Rougeon F, Corvol P (1985) Nonproportional changes on plasma renin concentration, renal renin content and rat renin messenger RNA. Hypertension 7:855-859

Nishizuka Y (1984) Turnover of inositol phospholipids and signal transduction. Science 225:1365-1369

Obana K, Naruse K, Sakurai H, Demura H, Inagami T, Shizume K (1985) Synthetic atrial natriuretic factor inhibits in vitro and in vivo renin secretion in rats. Endocrinology 117:1282-1285

O'Neal SG, Rhoads DB, Rador E (1979) Vanadate inhibition of sarcoplasmic reticulum $\mathrm{Ca}^{2+}$-ATPase and other ATPases. Biochem Biophys Res Commun 89:845-850

Opengorth TJ, Zehr JE (1983) Role of calcium in the interaction of alpha and beta adrenoreceptor-mediated renin release in isolated constant pressure perfused rabbit kidneys. J Pharmacol Exp Ther 227:144-149

Osswald $\mathrm{H}$ (1984) The role of adenosine in the regulation of glomerular filtration rate and renin secretion. Trends Pharmacol Sci 5:94-97

Osswald H, Hermes HH, Nabakowski G (1982) Role of adenosine in signal transmission of tubuloglomerular feedback. Kidney Int 22:S136-S142

Otsuki M, Okabayashi Y, Ohki A, Nakumara T, Tani S, Fujii M, Oka T, Sankaran H, Baba S (1986) Effect of $\mathrm{Bt}_{2} \mathrm{cGMP}$ on action of cholecystokinin in isolated perfused rat pancreas. Am J Physiol 251:G293-G299

Panthier JJ, Foote S, Chambraud B, Strosber AD, Corvol P, Rougeon F (1982) Complete amino acid sequence and maturation of the mouse submaxillary gland renin precursor. Nature 298:90-92

Park CS, Malvin RL (1978) Calcium in the control of renin release. Am J Physiol 235:F22 - F25

Park CS, Han DS, Fray JCS (1981) Calcium in the control of renin secretion: $\mathrm{Ca}^{2+}$ influx as an inhibitory signal. Am J Physiol 240:F70-F74

Park CS, Honeyman TW, Chung ES, Lee JS, Sigmon DH, Fray JCS (1986) Involvement of calmodulin in mediating inhibitory action of intracellular $\mathrm{Ca}^{2+}$ on renin secretion. Am J Physiol 251:F1055-F1062

Peart WS, Quesada T, Tengi I (1975) The effects of adenosine $3^{\prime}-5^{\prime}$-monophosphate and theophylline on renin secretion in the isolated perfused kidney of the rat. $\mathrm{Br} \mathrm{J}$ Pharmacol 54:55-60

Pedraza-Chaveri J, Ibarra-Rubio ME, Alatorre-Gonzalez MC, Pena JC, Garcia-Sainz JA (1985) Pertussis toxin potentiates anesthesia-induced renin secretion. Eur J Pharmacol 112:115-117

Pedraza-Chaveri J, Alatorre-Gonzalez MC, Pena JC, Garcia-Sainz JA (1986) Pertussis toxin enhances the beta-adrenergic and blocks the alpha $_{2}$-adrenergic regulation of renin secretion in renal cortical slices. Life Sci 38:1005-1011

Penner R, Neher E (1988) The role of calcium in stimulus-secretion coupling in excitable and non-excitable cells. J Exp Biol 139:329-345

Perrin D, Langley O, Amis D (1987) Anti- $\alpha$-fodrin inhibits secretion from permeabilized chromaffin cells. Nature 326:498-501

Persson BE, Sakai T, Marsh DJ (1988) Juxtaglomerular interstitial hypertonicity in Amphiuma: tubular origin-TGF signal. Am J Physiol 254:F445-F449

Peter S (1976) Ultrastructural studies on the secretory process in the epitheloid cells of the juxtaglomerular apparatus. Cell Tissue Res 168:45-53

Petersen OH, Maruyama Y (1984) Calcium-activated potassium channels and their role in secretion. Nature 307:693-696 
Pfeilschifter J, Kurtz A, Bauer C (1985) Inhibition of renin release by platelet activating factor (acetylglyceryl ether phosphorylcholine) in cultured rat juxtaglomerular cells. Biochem Biophys Res Commun 127:903-910

Phillis JW, Wu PH (1981) Catecholamines and the sodium pump in excitable cells. Prog Neurobiol 17:141-184

Pinet F, Corvol MT, Dench F, Bourguignon J, Fenntenn J, Menard J, Corvol P (1985) Isolation of renin-producing human cells by transfection with three simian virus 40 mutants. Proc Natl Acad Sci USA 82:8503-8507

Pinet F, Mizrahi J, Laboulandine I, Menard J, Corvol P (1987) Regulation of prorenin secretion in cultured human transfected juxtaglomerular cells. J Clin Invest 80:724-731

Porter JP, Said SJ, Ganong WF (1983) Vasoactive intestinal peptide stimulates renin secretion in vitro: evidence for a direct action of the peptide on the renal juxtaglomerular cells. Neuroendocrinology 36:404-408

Powell HR, McCredie DA, Rotenberg E (1978) Renin release by thyroid hormone. Endocrinology 103:985-989

Pratt RE, Quellette AJ, Dzau VJ (1983) Biosynthesis of renin: multiplicity of active and intermediate forms. Proc Natl Acad Sci USA 80:6809-6813

Raguki H, Nakamura M, Saito H, Higaki J, Ogihara T (1988) Endothelin inhibits renin release from isolated rat glomeruli. Biochem Biophys Res Commun 155:1244-1247

Rasmussen H (1986) The calcium messenger system. N Engl J Med 314:1094-1101, 1164-1170

Rasmussen H, Barrett PQ (1984) Calcium messenger system. An integrated review. Physiol Rev 64:938-984

Rightsel WA, Okamura T, Inagami T, Pitcock DA, Taki Y, Brooks B, Brown P, Muirhead EE (1982) Juxtaglomerular cell culture contain renin, angiotensin I converting enzyme and angiotensin I and II/III. Circ Res 50:822-829

Rogers J, Highes RG, Matthews EK (1988) Cyclic GMP inhibits protein kinase C-mediated secretion in rat pancreatic acini. J Biol Chem 263:3713-3719

Rossi N, Churchill PC, Churchill MC (1987) Pertussis toxin reverses adenosine receptor-mediated inhibition of renin secretion in rat renal cortical slices. Life Sci 40:481-487

Rouiller C, Orci L (1971) The structure of the juxtaglomerular complex. In: Rouiller C, Muller AF (eds) The kidney. Morphology, biochemistry, physiology, vol IV. Academic, New York, pp $1-80$

Ruyler JHC (1964) Studies on an improved lead phosphate technique for the demonstration of nonspecific and phosphatase in nondeparaffinized organ and tissue sections. Histochemie $3: 521-537$

Ryan GB, Alcorn D, Coghlan JP, Hill PA, Jacobs R (1982) Ultrastructural morphology of granule release from juxtaglomerular myoepitholid and peripolar cells. Kidney Int 22 [Suppl 12]:53-86

Sagnella GA, Peart WS (1979) Studies on the isolation and properties of renin granules from the rat kidney cortex. Biochem J 182:301-309

Schwertschlag U, Hackenthal E (1983) Short communication: trifluoperazine antagonizes inhibition of renin release by angiotensin II. Clin Exp Pharmacol Physiol 10:605-608

Sealy JE, Glorios N, Itskovitz J, Laragh JH (1986) Prorenin as a reproductive hormone. Am J Med 81:1041-1046

Seeman P (1972) The membrane actions of anesthetics and transquilizers. Pharmacol Rev 24:583-655

Sherline PY, Lee Y, Jacobs SL (1977) Binding of microtubules to pituitary secretion granule and secretory granule membranes. J Cell Biol 72:380-389

Skinner S, McCubbin JW, Page IH (1964) Control of renin secretion. Circ Res 15:64-76

Skott O (1986) Pulsatile renin release from single juxtaglomerular apparatus. Renal Physiol 9:61

Skott O (1988) Do osmotic forces play a role in renin secretion? Am J Physiol 255:F1 - F10

Skott O, Baumbach L (1985) Effects of adenosine on renin release from isolated glomeruli and kidney slices. Pflügers Arch 404:232-237 
Skott O, Briggs JP (1987) Direct demonstration of macula densa mediated renin release. Science 237:1618-1620

Skott O, Taugner R (1987) Effects of extracellular osmolality on renin release and on the ultrastructure of the juxtaglomerular epitheloid cell granules. Cell Tissue Res 249:325-329

Smith JM, Moun DR, Vander AJ (1979) Effect of parathyroid hormone on plasma renin activity and sodium excretion. Am J Physiol 236:F311-F319

Spielman WS, Thompson CJ (1982) A proposed role for adenosine in the regulation of renal hemodynamics and renin release. Am J Physiol 242:F423 - F435

Streb H, Irvine RF, Berridge MJ, Schulz I (1983) Release of $\mathrm{Ca}^{2+}$ from a nonmitochondrial store in pancreas acinar cells by inositol-1,4,5-triphosphate. Nature 306:67-68

Taher MS, McLain LG, McDonald KM, Schrier RW (1976) Effect of beta-adrenergic blockade on renin response to renal nerve stimulation. J Clin Invest 57:459-465

Takagi M, Takagi M, Franco-Saenz R, Mulrow PJ (1988) Effect of atrial natriuretic peptide on renin release in a superfusion system of kidney slices and dispersed juxtaglomerular cells. Endocrinology 122:1437-1442

Takahashi S, Murakami K, Miyake Y (1982) Activation of kidney prorenin by kidney cathepsin B isoenzymes. J Biochem 91:419-422

Tanita T (1988) Ionic channels in smooth muscle studied with patch-clamp methods. Jpn J Physiol 38:1-18

Taugner R, Bührle CP, Hackenthal E, Mannek E, Nobiling R (1984) Morphology of the juxtaglomerular apparatus and secretory mechanisms. In: Berlyne GM, Giovanetti S (eds) Contributions of nephrology, vol 43. Karger, Basel, pp 76-101

Taugner R, Whalley A, Angermüller S, Bührle CP, Hackenthal E (1985 a) Are the renin containing granules of juxtaglomerular cells modified lysosymes? Cell Tissue Res 239:575-587

Taugner R, Bührle CP, Nobiling R, Kirschke H (1985b) Coexistence or renin and cathpepsin $B$ in epitheloid cell secretory granules. Histochemistry 83:103-108

Taugner R, Yokota S, Bührle CP, Hackenthal E (1986) Cathpepsin D coexists with renin in the secretory granules of juxtaglomerular epitheloid cells. Histochemistry 84:19-22

Taugner R, Kim SJ, Murakami K, Waldherr R (1987) The fate of prorenin during granulopoiesis in epitheloid cells. Histochemistry 86:249-253

Taugner R, Nobiling R, Metz F, Taugner F, Bührle CP, Hackenthal E (1988) Hypothetical interpretation of the calcium paradox in renin secretion. Cell Tissue Res 252:687-690

Tobian L (1960) Interrelationship of electrolytes, juxtaglomerular cells, and hypertension. Physiol Rev 40:280-312

Tremblay J, Gerzer R, Vinay P, Pang SC, Beliveau R, Hamet P (1985) The increase of cGMP by atrial natriuretic factor correlates with the distribution of particulate guanylate cyclase. FEBS Lett 181:17-22

Trifaro JM, Bader MF, Doucet JP (1985) Chromaffin cell cytosceleton: its possible role in secretion. Can J Biochem Cell Biol 63:661-679

Ueda J, Nakanishi H, Abe Y (1978) Effect of glucagon on renin secretion on the dog. Eur J Pharmacol 52:85-92

Vallotton MB (1987) The renin-angiotensin system. Trends Pharmacol Sci 8:69-74

van Breemen C, Aaronson P, Loutzenhiser R (1979) Sodium calcium interactions in mammalian smooth muscle. Pharmacol Rev 30:167-208

Vandongen R (1975) Inhibition of renin secretion in the isolated rat kidney by antidiuretic hormone. Clin Sci Mol Med 49:73-76

Vandongen R, Peart WS (1974) Calcium dependence of the inhibitory effect of angiotensin on renin secretion on the isolated perfused kidney of the rat. Br J Pharmacol 50:25-29

Vandongen R, Peart WS, Boyd GW (1973) Adrenergic stimulation of renin secretion on the isolated perfused rat kidney. Circ Res 32:290-296

Vidal MJ, Romero JC, Vanhoutte PM (1988) Endothelium-derived relaxing factor inhibits renin release. Eur J Pharmacol 149:401-402

Viskoper RJ, Maxwell MH, Lupu AN, Rosenfield (1977) Renin stimulation by isoproterenol and theophylline in the isolated perfused kidney. Am J Physiol 232:F248-F253 
Watkins BE, Davies JO, Lohmeier TE, Freeman RH (1976) Intrarenal site of action of calcium on renin secretion in dogs. Circ Res 39:847--853

Weber PC, Larssen C, Angaard E, Hamberg M, Corey EJ, Nicolaou KC, Samuelsson B (1976) Stimulation of renin released from rabbit renal cortex by arachidonic acid and prostaglandin endoperoxides. Circ Res 39:868-874

Werning C, Vetter W, Weidmann P, Schwickert HU, Stiel D, Siegenthaler W (1971) Effect of prostaglandin $E_{1}$ on renin in the dog. Am J Physiol 220:852-856

Yokosawa N, Takahashi N, Inagami T, Page DL (1979) Isolation of completly inactive plasma prorenin and its activation by kallikreins. A possible new link between renin and kallikrein. Biochim Biophys Acta 569:211-219

Zavagli G, Aleotti A, Farinelli A (1983) Human renin granules: ultrastructural aspects. Nephron 33:29-33 